\title{
The mine tailings as construction material in the viceregal period: case study in Guanajuato City, Mexico
}

\author{
María Jesús Puy-Alquiza, Raúl Miranda-Avilés, Velia Yolanda Ordaz Zubia, Cristina Daniela Moncada,
} Gabriela Ana Zanor, Ma. Del Carmen Salazar-Hernández, Yanmei Li, Isidro Loza-Aguirre

María Jesús Puy-Alquiza

yosune.puy155@gmail.com

Raúl Miranda-Avilés

Gristina Daniela Moncada

Yanmei Li

Isidro Loza-Aguirre

Departamento de Minas, Metalurgia y Geología, División de Ingenierías, Universidad de Guanajuato, Campus Guanajuato, Mexico.

\section{Velia Yolanda Ordaz Zubia}

Departamento de Arquitectura, División de Arquitectura, Arte y Diseño, Universidad de Guanajuato, Campus Guanajuato, Mexico.

\section{Gabriela Ana Zanor}

División de Ciencias de la Vida (DICIVA), Universidad de Guanajuato, Irapuato, Guanajuato, Mexico.

\section{Ma. Del Garmen Salazar-Hernández} Unidad Profesional Interdisciplinaria de Ingeniería Campus Guanajuato, Instituto Politécnico Nacional, Av. Mineral de Valenciana No. 200, Col. Fraccionamiento. Industrial Puerto Interior, 36275 Silao de la Victoria, Guanajuato, Mexico.

BOL. SOC. GEOL. MEX. 2019

VOL. 71 NO. 2

P. $543-564$

http://dx.doi.org/10.18268/BSGM2019v7 1n2a18

\section{ABSTRACT}

The colonization of Guanajuato and its environs began in the decade of 1540-1550, when some Spaniards entered the territory of Guanajuato for the purpose of the distribution of ranches, in search of valuable minerals, and to evangelize. In the following years, the silver-gold deposits were discovered. From the earliest records, it can be deduced that the mineral deposits were discovered in about 1552, and more intensely in the year 1557. Mining production generated large amount of mine tailings. The first mining haciendas were established along the Guanajuato River, promoting the human settlements and development of the city of Guanajuato. The haciendas in Guanajuato were a very well-developed economic system. As they grew up, they became federal states, which wer self-sufficient with their main objective to benefit from the ore obtained from the mines. The design and architectural style of these haciendas were determined by their activity, so, the material they used for their construction was adobes composed of mud and mine tailings, taken from the surroundings of the Guanajuato River. In this work, we study the physical, mechanical and chemical properties of six samples of adobe bricks, collected from several buildings of the seventeenth and eighteenth centuries in Guanajuato city (Mining Hacienda San Juan Nepomuceno, Mining Hacienda San Jeronimo, Mining Hacienda Duran, Mining Hacienda San Clemente, Mining Hacienda Purisima and Mining Hacienda Rayas) in Mexico. The adobe specimens were investigated by the techniques of Inductively Coupled Plasma Mass Spectrometry, X-Ray Diffraction and Scanning Electron Microscopy, in order to know their chemical and mineralogical composition; likewise, some analyzes were performed to determine their mechanical properties (simple compressive strength), physical properties (granulometry, real density, total porosity and moisture content), and biological properties (organic material content). These studies aim to establish a basis of knowledge, essential for the safety assessment of adobe constructions, and to contribute to the conservation of the adobe architecture. The analytical results support that the six adobe samples exhibited different behavior, depending on the property tested. Adobe samples have a higher percentage of fines $(70 \%)$. According to the Unified Soil Classification System, the adobes studied correspond to silt of low compressibility. Inductively Coupled Plasma Mass Spectrometry analysis showed that adobe bricks share the same chemical composition, varying the concentration of heavy metals $(\mathrm{Cu}, \mathrm{Be}, \mathrm{Zn}, \mathrm{Sn}, \mathrm{Pb}, \mathrm{Ni}, \mathrm{Co}, \mathrm{V}, \mathrm{Sb}$, $\mathrm{Hg}$ and $\mathrm{Cr}$ ). The $\mathrm{Cu}, \mathrm{Zn}, \mathrm{Pb}$ and $\mathrm{Sn}$ presented in the adobes indicate that they were the product of a metallurgical process. The presence of $\mathrm{Hg}$ indicates that the method of benefit was by amalgamation used in the sixteenth, seventeenth and eighteenth centuries in the New Spain to obtain silver. With respect to the results obtained in X-Ray Diffraction, we confirmed the presence of 17 major minerals: Quartz, Orthoclase, Calcite, Faujasite Na and K, Erionite-K, Gismondine, Illite, Schuetteite, Sphalerite, Zinkenite, Sanidine, Sidorenkite, Zircon, Sepiolite, Brushite, Fizelyte and Gypsum; most of them are the product of the process of benefit of the mineral by the method of amalgamation.

Keywords: mine tailings, mining hacienda, viceregal period, Guanajuato city, Inductively Coupled Plasma Mass Spectrometry, X-Ray Diffraction.

\section{RESUMEN}

La colonización de la cañada de Guanajuato y sus alrededores inició en la década de 1540-1550, cuando algunos españoles entraron al territorio guanajuatense con motivo de la repartición de estancias ganaderas, en busca de minerales valiosos y a evangelizar. En los siguientes años se descubrieron los yacimientos de plata-oro. De los primeros registros se deduce que los yacimientos mineros se descubrieron hacia 1552, y de una manera más intensa en el año 1557. La producción minera generó grandes cantidades de jales mineros. Las primeras haciendas mineras se establecieron a lo largo del río Guanajuato, las cuales dieron origen a la ciudad de Guanajuato. Las haciendas de Guanajuato eran un sistema económico muy bien desarrollado. A medida que crecieron, se convirtieron en estados federales que eran autosuficientes, y su principal objetivo era beneficiar el mineral obtenido de las minas. El diseño y el estilo arquitectónico de estas haciendas fueron determinados por su actividad, por lo que el material que utilizaron para su construcción fueron adobes creados por barro y jales de minas, extraidos de los alrededores del río Guanajuato. En este trabajo se estudian las propiedades fisicas, mecánicas y químicas de seis muestras de adobes recolectados en varios edificios de los siglos XVII y XVIII en la ciudad de Guanajuato (Hacienda Minera San Fuan Nepomuceno, Hacienda Minera San ferónimo, Hacienda Minera Duran, Hacienda Minera San Clemente, Hacienda Minera Purísima y Hacienda Minera Rayas) en México. Los especimenes de adobe fueron investigados mediante técnicas de Espectrometría de Masas de Plasma Acoplado Inductivamente, Difracción de Ravos X y Microscopía Electrónica de Barrido, para conocer la composición química y mineralógica. Se determinaron propiedades mecánicas (resistencia a la compresión simple), propiedades fisicas (granulometría, densidad real, porosidad total y contenido de humedad), y las propiedades biológicas (contenido de materia orgánica). Estos estudios pretenden establecer una base de conocimiento para la evaluación de la seguridad de las construcciones de adobe, y contribuir a la conservación de la arquitectura del adobe. Los resultados obtenidos indican que las seis muestras de adobe mostraron un comportamiento diferente. Las muestras de adobe tienen un mavor porcentaje de limos (70\%). De acuerdo con el Sistema Unificado de Clasificación de Suelos, los adobes estudiados corresponden a limos de baja compresibilidad. El análisis realizado con la Espectrometría de Masas de Plasma Acoplado Inductivamente muestra que los adobes comparten la misma composición mineralógica, variando la concentración de metales pesados (Cu, Be, Zn, $\mathrm{Sn}, \mathrm{Pb}, \mathrm{Ni}, \mathrm{Co}, \mathrm{V}, \mathrm{Sb}, \mathrm{Hg}$ y $\mathrm{Cr}$ ). $\mathrm{El} \mathrm{Cu}, \mathrm{Zn}, \mathrm{Pb}$ y Sn presentes en los adobes indican que fueron el producto de un proceso metalúrgico. La presencia de $\mathrm{Hg}$ indica que el método de beneficio fue la amalgamación utilizada en los siglos XVI, XVII y XVIII en la Nueva España para obtener plata. Con respecto a los resultados obtenidos en Difracción de Rayos X, se muestra la presencia de 17 minerales principales: Cuarzo, Ortoclasa, Calcita, Faujasita Na y K, Erionita-K, Gismondina, Illite, Schuetteite, Esfalerita, Zinkenita, Sanidina, Sidorenkita, Zircon, Sepiolite, Brushite, Fizelyte y Gypsum; la mayoría de ellos son producto del proceso de beneficio del mineral por el método de amalgamación

Palabras clave: jales, haciendas de beneficio, periodo virreinal, ciudad de Guanajuato, Espectrometría de Masas de Plasma Acoplado Inductivamente, Difracción de Rayos $X$. 


\section{Introduction}

Adobe mud blocks are a common prehistoric building material, widely used for thousands of years by indigenous peoples of America in the southwestern United States, Mesoamerica, Africa, the Indian subcontinent and other parts of Asia, the Middle East, and Southern Europe (Houben and Guillard, 1994; Jiménez-Delgado and Canas-Guerrero, 2006). Through Spanish conquests of the New World, the word "adobe" was brought to the Americas (Smith and Austin, 1989). Among the earliest remains of adobe structures are those discovered in the ruins of Neolithic farming villages in Mesopotamia, dating as far back as 7000 BCE (Steen, 1977). The Egyptian civilization was the first to use the raw earth for building since $10^{\text {th }}$ Millennium BCE (Heathcote, 1995; Kemp, 1999; Atzeni et al., 2008). Constructions of 8000 to 6000 BCE have been found in Turkestan and Assyria (4000 BCE). Throughout the history of Mexico, the earth has also been used as the raw basic building material, example for this are the efficient architectural developments of Aztecs from the West Mexico, the Valley of Oaxaca and the Maya lowlands. The Maya of Mexico and Central America developed adobe bricks before the arrival of the Spanish in the early XVI century, while the Indians of the southwestern United States did not use adobe until the Spanish introduced it in the seventeenth century. The Arabs brought adobe to Spain during their $800^{\text {th }}$ year occupation of the Iberian Peninsula. During the Spanish Colonial period, most of adobe buildings erected were used for domestic purposes. The origin of the haciendas, in which they developed farming, ranching and mining, is in the late sixteenth century. It happened at first in contiguous locations in the mining centers to supply them. Later, in the seventeenth century, they consolidated as interdependent economic units that took the abundant availability of labor, mostly indigenous, which was gathered by Spanish capitals around strategy, which facilitated the process of domination. Haciendas in Mexico were an economic system during the period between the Conquest and the Mexican Revolution. The origin was given to a system during that time, which granted land by the conquerors and Spanish in exchange for military service. As farms grew, they became states, which were self-sufficient, and their main objective was to exploit land and safe keep it from bandits and looters. The haciendas were "operated by a dominant landowner and a dependent labor force, organized to supply a small-scale market by means of scarce capital accumulation, but also to support the status aspirations of the owner" (Wolf and Mintz, 1957). Some haciendas were enormous landholding fiefdoms, whose structure and labor force paralleled New World plantations, although hacienda workers were not legally slaves (Gonzalez Sanchez, 1997); however, due to many factors, including debt peonage, indigenous hacienda peons led lives similar to those of plantation slaves in the Caribbean and southern United States (Meyers and Carlson, 2002). In Mexico, the hacienda has long been a focus of historical research, leaving no doubt as to the importance of the institution in the Mexican history, economy and society (Chevalier, 1963; Taylor, 1972; Morner, 1973; Van Young, 1983; Jarquín et al., 1990; Brannon and Joseph, 1991, Chance, 2003). The Mexican hacienda was more than simply a large agricultural estate. With the establishment of each new hacienda, there came a social and physical reordering of an ancient landscape.

The hacienda system brought European conquerors and indigenous conquered into daily contact and provided a locus for the generation and institutionalization of the new class, ethnic and racial identities. As such, the hacienda lends itself well to anthropological investigation, as evidenced by the growing number of archaeological projects in several regions. Recently, Mexican hacienda research has produced a small, but growing number of archaeological studies (Benavides, 1985; Meyers and Carlson, 2002; Alexander, 2004; Meyers, 2005). An important distinguishing 
attribute of these investigations has been their strong anthropological problem orientation (Alexander, 1997; Fournier-Garcia, 1997; Fournier Garcia and Mondragon, 2003; Liberotti and Daneels, 2012), that can be grouped into three types: studies that are historically based, but archaeologically relevant, because they describe events and processes of hacienda development with linkages to broader cultural patterns; studies of hacienda archaeological settlement patterns; and studies with an excavation focus.

The design and architecture of the hacienda were determined by the activity developed therein. For example, in Guanajuato, since the discovery of the San Bernabe vein, not only begins the history of mining in the district of Guanajuato, but also the state capital, and from this date, both the progress and development of both.

During XVII and XVIII centuries, the benefit of silver was made by the method of amalgamation that is also known as "patio". The amalgamation method was the most important technical innovation in the mining of the XVI century that allowed obtaining pure silver at low cost and at greater amounts that could be refined for profit, for that reason, it was used mainly as a low-grade mineral. The amalgamation method consisted of grinding the material extracted from the mine to a size of $8 \mathrm{~mm}$ in diameter, later this material was passed through trawls where it was re-worked, reducing the ore to the size of silt clays, adding water, common salt and quicksilver (mercury) to form a paste called "torta". The "torta" was moved with shovels or walking on it, so that the mercury was well incorporated and left to rest for three months. Then the "torta" was washed to separate the earth and the impurities from the metal elements, obtaining a material called "pella", which was placed in canvas bags, so that the mercury would flow leaving a solid mass called "piña". The "piña" was heated under a bell (capellina), so that the mercury was evaporated and recovered by cooling. The pure silver was then melted into bars (Antúnez, 1964). Based upon this process, the haciendas arose in the seventeenth century, with the aim of promoting the development of local mining by the method of benefit of quicksilver, its main cast obtaining silver (Figure 1). They had vast tracts of land with a housing area called "hull of the hacienda". The "hull of the hacienda" is the main house where the owners of the hacienda lived. Next to the main house, the" hull of the hacienda" had a chapel, workers' houses, administrative buildings, store, garden, stables, corrals for cattle, wineries harvest storage, laundries, foundry furnaces, and mills. During the mining process, it was common in the mining district of Guanajuato to dispose of the tailings derived from mining and metallurgical operations by throwing them into the river channels, which caused the rivers to become silted, which in turn during the rainy season caused numerous floods severely affecting the population. To avoid this situation, the government prohibited the mining waste to be thrown into the river, therefore, the use of this waste was the manufacture of adobes. Nowadays, there are few studies related to the elaboration and regulation in the use of constructive materials from mining waste (Orozco and Orozco, 1992; Sengupta, 1993). This study contributes to the characterization of adobe bricks, traditionally used in Guanajuato city during the viceregal period, and provides reference values that can be considered as geological materials in restauration processes for mining haciendas.

\section{Study area}

For the experimental test campaign, a set of six samples of different types of adobe construction belonging to the 17th and 18th centuries was selected. Based on this, six mining haciendas (San Juan Nepomuceno, San Clemente, Duran, La Purisima, San Jeronimo and Rayas) were chosen, distributed in different points of the city of Guanajuato (Figure 1). The samples were constituted, whenever possible, by whole blocks of adobe, whose dimensions were $0.45 \mathrm{~m}$ x 0.35 

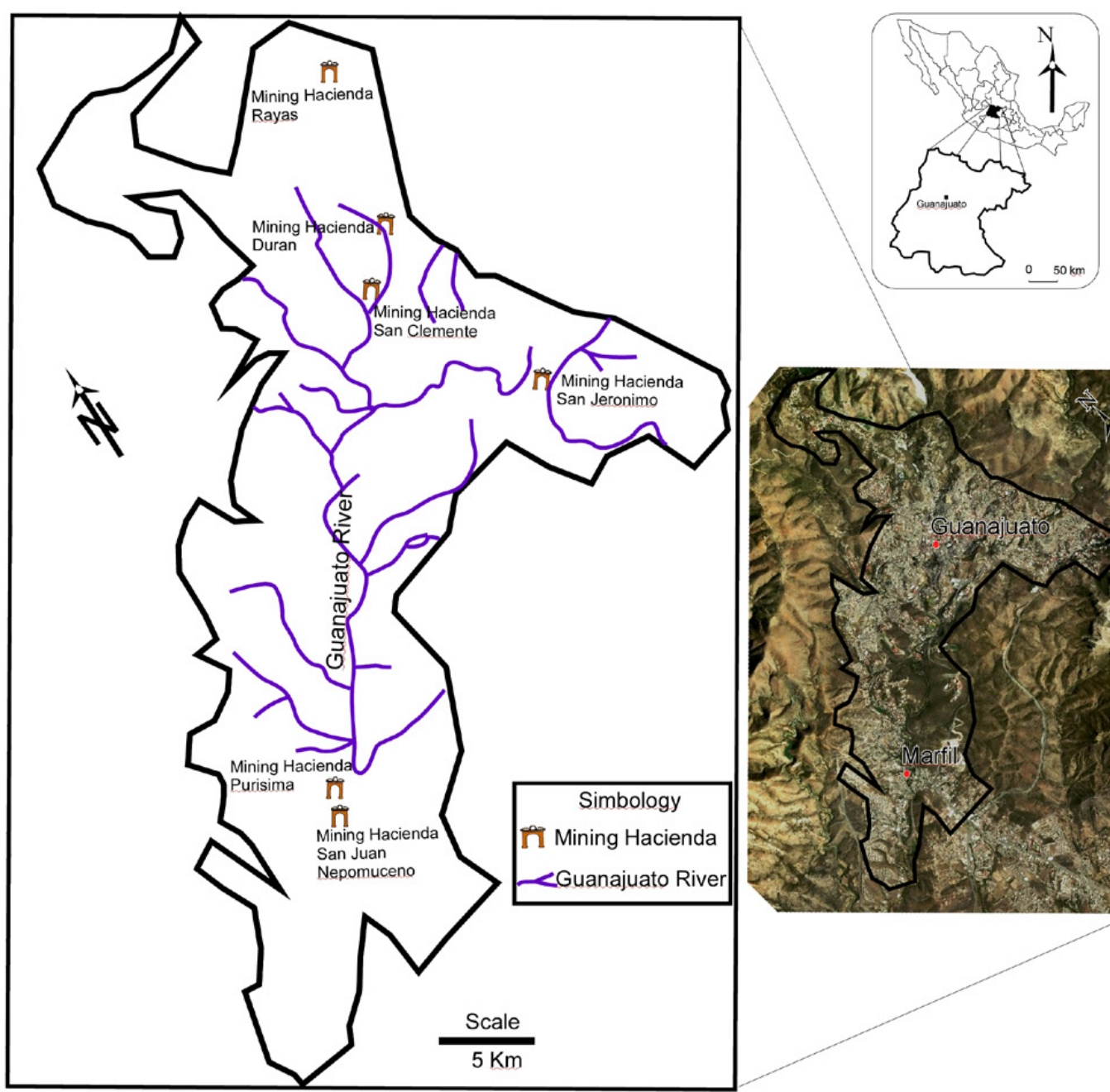

General map of Guanajuato city showing the seven buildings studied.

$\mathrm{m} \times 0.12 \mathrm{~m}$. The blocks studied were part of the hacienda's galleys, a space designed to grind the ore by means of stone mills moved by mules. According to the catalog of historic buildings (Camarillo-Ramirez and Cortez-Barroso, 2015), we can say that the mining haciendas were built in the late seventeenth and early eighteenth century. These consisted of a chapel, gallery, mills, one or more wash tubs, water wheel, warehouses, barn, chambers, ovens, and stables.

\subsection{DESCRIPTION OF THE SEVENTEENTH AND EIGHTEENTH GENTURY BUILDINGS STUDIED}

The discovery in the 16th century of the silver vein in the Mineral de la Luz initiates the exploitation of the mineral wealth in the Mining District of Guanajuato. This discovery led to the formation of haciendas built for the sole purpose of mining, in particular the smelting or amalgamation of silver. These haciendas were in fact the first buildings in various parts of the New Spain.

In Guanajuato, the morphology of the settlement was determined by the route that followed both the main river and other currents that in times of rain became important. The haciendas then emerged in the sixteenth century, promoting the development of local mining by means of silver amalgamation. The haciendas in their beginnings occupied what nowadays is the center of the city; by the eighteenth century, they had moved to outside of the city being located on the banks of 
the main river. The Bourbon reforms (1765-1808) caused the proliferation of haciendas throughout the mining district of Guanajuato, concentrating mainly in an industrial corridor that began towards the north of the city and continuing towards the east with the hacienda of Duran, Rayas and San Clemente. The hacienda that was occupying a space in the interior of the city was San Jeronimo, and to the south, there were located the haciendas of San Juan Nepomuceno and La Purisima (Figures 2, 3 and 4).

\section{Methodology}

The research was developed in three distinct phases: the first one was aimed at surveying the adobe typology by applying mechanical, biological and physical parameters of the materials sampled, such as: physical tests (granulometry, real density, total porosity, moisture content), biological tests (organic material content), and mechanical tests (simple compressive strength) to evaluate their use in construction and restoration

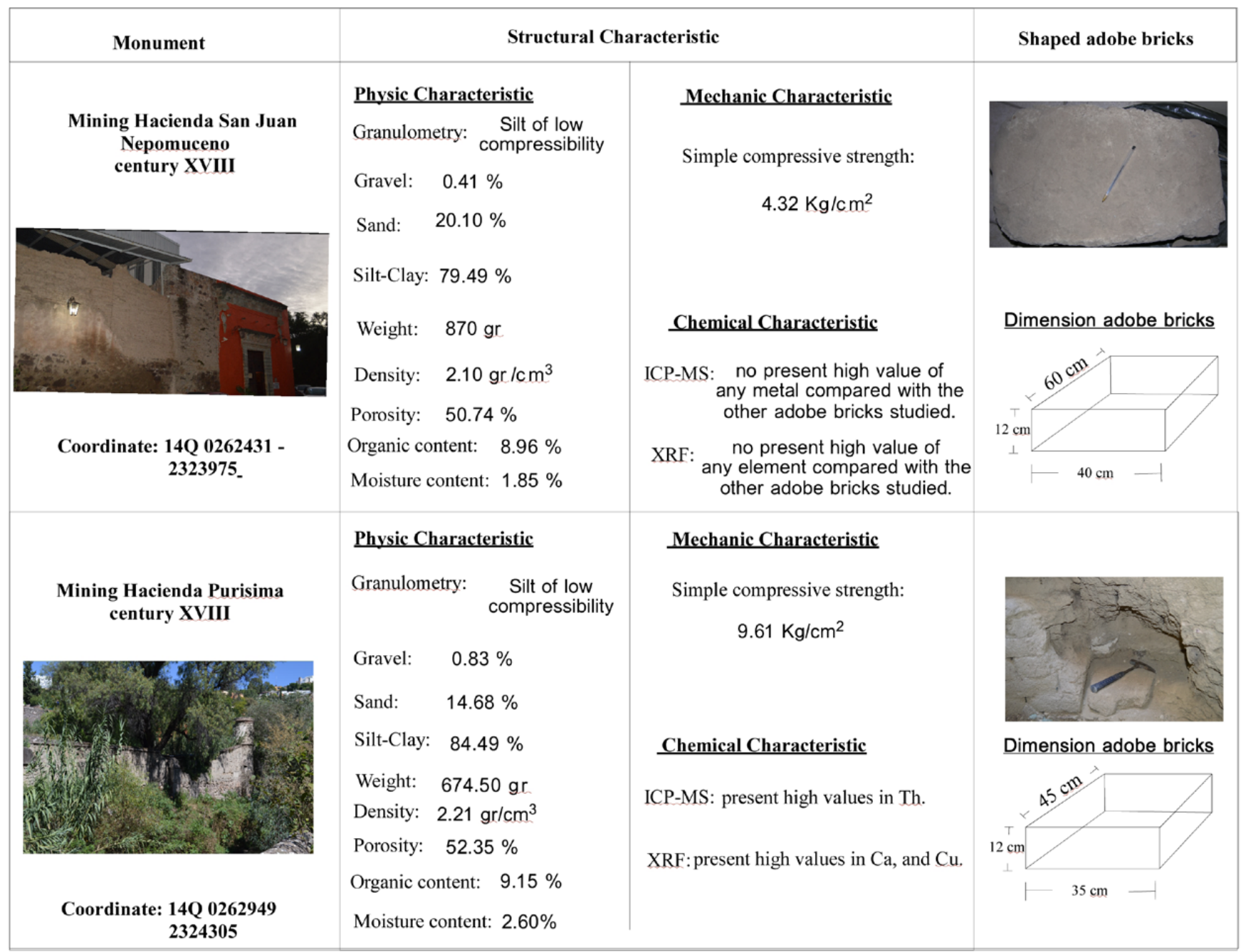




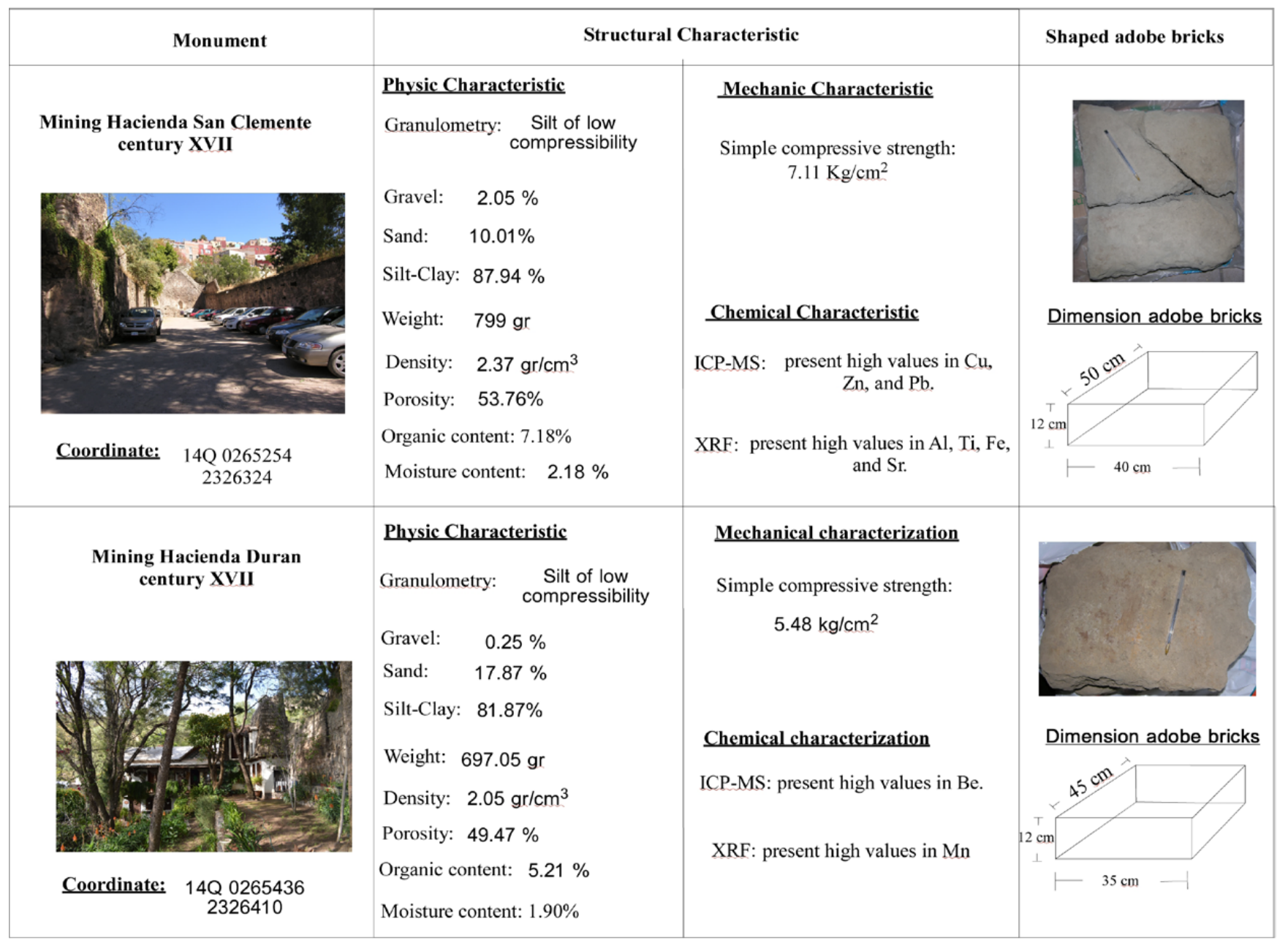

Figure 3 General characteristics of the mining haciendas San Clemente and Duran.

of monuments. The second phase was the application of chemical characterization and morphology analysis using the techniques of Inductively Coupled Plasma Mass Spectrometry (ICP-MS), X-Ray Diffraction (XRD) and Scanning Electron Microscopy (SEM-EDS). The third phase consisted in the interpretation of the results obtained.

\subsection{MEGHANIGAL AND PHYSICAL CHARACTERIZATION}

\subsubsection{PHYSICAL TEST}

Physical characterization tests provided the granulometry, real density, total porosity and moisture content.

\subsubsection{GRANULOMETRY}

The particle size distribution was obtained by sieving. Sieve analysis was carried out according to ASTM D2487-11 standard. The samples were classified considering the Unified Soil Classification System (USCS).

\subsubsection{REAL DENSITY}

Real Density tests were carried out on seven specimens, applying the European Standard UNE-EN 1936, (2006). The seven specimens used for this test had a cubic shape $(8 \mathrm{~cm} \times 8 \mathrm{~cm} \times 8 \mathrm{~cm})$. The real density was calculated using the relationship between the mass and the volume (Equation 1).

$$
\operatorname{Pr}=\mathrm{me} / \mathrm{Vs}(\mathrm{prh})
$$




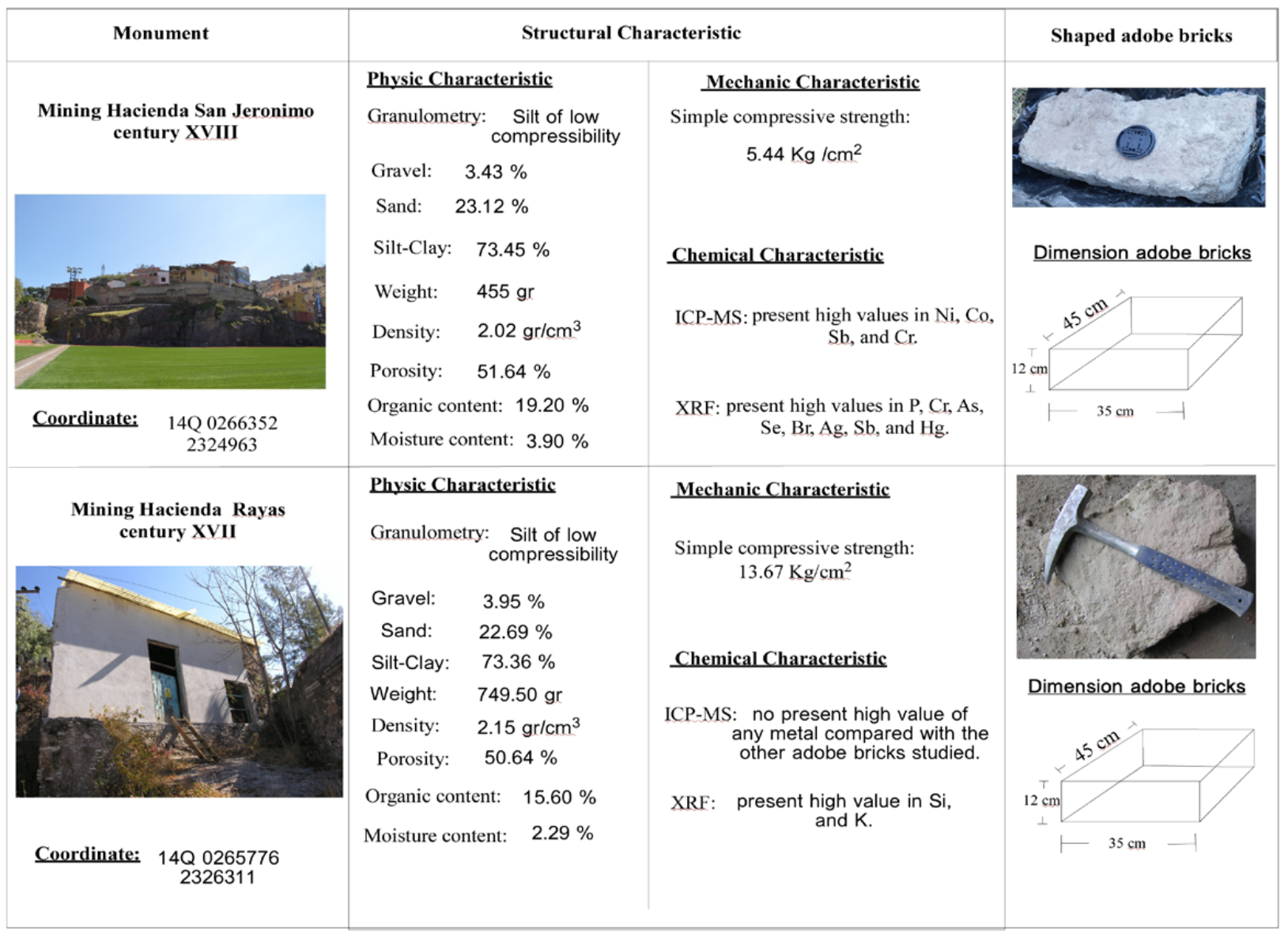

Figure 4 General characteristics of the mining haciendas San Jeronimo and Rayas.

Where (me) is the mass of crushed and dry specimen in grams; $(V s)$ is the volume of liquid displaced by the mass; (prh) water density in kilograms per cubic meter.

\subsubsection{TOTAL POROSITY}

The total porosity test was carried out on seven specimens, applying the European Standard UNE-EN 1936, (2006). Total porosity was calculated using the relationship between the volume of the pores (open and closed) and the apparent volume of the specimen (Equation 2).

$$
\mathrm{p}=(1-\mathrm{pb} / \mathrm{pr}) \times 100
$$

Where $(p b)$ is apparent density and $(p r)$ real density.

\subsubsection{MOISTURE GONTENT}

To determine the moisture content, a piece of adobe was cut and weighed. Subsequently, the cut piece was placed into the oven at a constant temperature of $105 \pm 5{ }^{\circ} \mathrm{C}$ for 24 hours. After this time, the sample was removed from the oven, allowed to cool and weighed. The moisture content was calculated considering the relative weight change between the initial weight and the dry weight of the sample.

\subsection{BIOLOGICAL TEST}

\subsubsection{ORGANIC MATERIAL CONTENT}

The total organic material test was carried out on seven species, applying the Mexican Standard NMX-AA-21-1985. Total organic material was calculated using the relationship between the volume of potassium dichromate, the ferrous sulfate and the sample weight (Equation 3).

Organic material $(\%)=(\mathrm{V} 1 . \mathrm{N} 1-\mathrm{VNF}) \mathrm{K} / \mathrm{P} \quad(3)$ Where $V 1=$ Volume of potassium dichromate 
solution used in the sample $\mathrm{cm}^{3} . \mathcal{N} 1=$ Normality of the solution of potassium dichromate. $V=$ volume of ferrous sulfate solution used in the titration of the sample in $\mathrm{cm}^{3} . \mathcal{N}=$ Normality of the solution of ferrous sulfate. $P=$ weight of sample. $K=0.003$.

\subsection{MEGHANICAL TEST}

\subsubsection{SIMPLE COMPRESSIVE STRENGTH TEST}

Simple compressive strength test was also performed to determine the maximum value of stress reached before failure. Simple compressive strength (UCS) tests were carried out on seven specimens, applying the European Standard Norm UNE-EN1926 (2006). The cubic samples $(8 \mathrm{~cm} \times 8 \mathrm{~cm} \times 8 \mathrm{~cm})$ were parallelly and perpendicularly cut to the sediment bedding to obtain information about mechanical isotropy. The testing device (Universal Press Forney apparatus) allowed a maximum axial load of $1471 \mathrm{kN}$. The axial load was increased continuously at a rate within the limits of rupture $(1367 \mathrm{kN})$. Load and strain were continuously registered; sampling time interval was between 2 and 6 min.

\subsection{GHEMICAL GHARACTERIZATION AND MORPHOLOGY ANALYSIS}

\subsubsection{ICP-MS ANALYSIS}

The chemical analyses of eleven metals $(\mathrm{Be}, \mathrm{Ni}$, $\mathrm{Co}, \mathrm{Sb}, \mathrm{Cr}, \mathrm{Cu}, \mathrm{Zn}, \mathrm{Sn}, \mathrm{Pb}$, Th and V) were carried out by ICP-MS, using a Thermo Series XII instrument at Centro de Geociencias-UNAM (Querétaro, Mexico). These metals were studied for their degree of toxicity and their relationship with the amalgamation method used in the mining industry in the seventeenth, eighteenth and nineteenth centuries. The samples were previously crushed to a size of $75 \mu \mathrm{m}$. For sample preparation, we used the methodology of Mori et al. (2009).

\subsubsection{XRD ANALYSIS}

To determine the nature of the minerals, the samples studied were analyzed using XRD model Rigaku, ULTIMA IV diffractometer at mineral research and characterization laboratory
(LICAMM), laboratory of the Guanajuato University, with CuKa radiation. A first fraction of seven powder samples of $0.0625 \mathrm{~mm}$ was obtained by sieving, which allowed the partial removal of the quartz. Subsequently, a fine fraction of $0.044 \mathrm{~mm}$ (Wentworth-Udden particle scale) was obtained, as described above. Both fractions were investigated by X-ray diffraction between $3^{\circ}$ and $90^{\circ} 2 \theta$, with a step width of 0.02 and $2 \mathrm{~s}$ data collection per step.

\subsubsection{SEM-EDS}

The morphological aspects of the adobe bricks were investigated by SEM observation without any metal coating. The SEM instrument (JEOL, JSM- 6010 PLUS/LA) was operated at $15 \mathrm{kV}$ in a low vacuum, while the energy dispersion scanner spectrometer (EDS), attached to the SEM, was used for semi-quantitative chemical analysis. The SEM-EDS analyses were carried out in the laboratory LICAMM of the Guanajuato University.

\section{Results}

\subsection{PHYSICAL AND BIOLOGICAL GHARAGTERIZATION OF ADOBES}

\subsubsection{GRANULOMETRY}

Apart from the mineralogical composition of the adobe, granulometry (grain size) is an essential aspect to be taken into account when characterizing adobe, since it provides insight into the type of raw material originally used to make the adobes. The commercially produced adobe contains 27 to $89 \mathrm{wt} \%$ sand-and-larger grain size, 8 to $68 \mathrm{wt} \%$ silt-size grains, and 1 to $15 \mathrm{wt}^{\%} \%$ clay-size grains (Smith and Austin, 1989; 1996).

Table 1 shows the size distribution of the particles that make up the adobes matrix studied. The grain size composition was 0.25 to $3.95 \mathrm{wt} \%$ gravel, 10.01 to $23.12 \mathrm{wt}^{\%} \%$ sand and 73.36 to 87.94 $w t \%$ silt-clay. According to the USCS, the adobes studied correspond to the three types of soil: $\mathrm{MH}$ : Inorganic silts, micaceous or diatomaceous fine Sandy of silty soils, elastic silts; ML: Inorganic 
silts and very fine sands, rock flour, silty of clayey fine sands or clayey silts with slight plasticity and CL: Inorganic clays of low to medium plasticity, gravelly clays, Sandy clays, silty clays, lean clays, (Table 1).

\subsubsection{REAL DENSITY AND TOTAL POROSITY}

The real density and total porosity are shown in Table 2. The adobe samples showed similar density values in terms of bulk density, the range of values shown by the bricks studied is 2.02 to 2.37 $\mathrm{g} / \mathrm{cm}^{3}$. Porosity is an important parameter due to its influence on properties, such as: chemical reactivity, mechanical strength, durability and the overall quality of the brick. The porosity of adobe bricks studied varies from 49.47 to $55 \%$.

\subsubsection{MOISTURE CONTENT AND ORGANIC MATERIAL CONTENT}

The moisture and organic material content are shown in Table 3.

The Hacienda San Jeronimo has the highest moisture content $(3.80 \%)$, followed by Hacienda Purisima (2.60\%), Hacienda Rayas (2.29\%), Hacienda San Clemente (2.18\%), Hacienda Duran (1.90\%) and Hacienda San Juan Nepomuceno $(1.85 \%)$.

The highest percentage of organic matter is presented in the Hacienda San Jeronimo (19.20\%), followed by the Hacienda Rayas (15.60\%),
Hacienda Purisima (9.15\%), Hacienda San Juan Nepomuceno (8.96\%), Hacienda San Clemente $(7.58 \%)$ and Hacienda Duran $(5.21 \%)$.

\subsection{MEGHANIGAL GHARACTERIZATION OF ADOBES}

\subsubsection{SIMPLE COMPRESSIVE STRENGTH TESTS}

The results of the mechanical tests are given in Table 4. These tests were conducted on specimens using perpendicular orientations. The results showed that the seven bricks samples exhibited different behavior. Hacienda Duran $\left(5.48 \mathrm{~kg} \mathrm{~cm}^{-2}\right)$, Hacienda San Jeronimo (5.44 $\left.\mathrm{kg} \mathrm{cm}^{-2}\right)$, Hacienda San Juan Nepomuceno (4.32 $\mathrm{kg} \mathrm{cm}^{-2}$ ) had a lower strength values, when the load was applied perpendicularly to the bedding planes, while Hacienda Rayas $\left(13.67 \mathrm{~kg} \mathrm{~cm}^{-2}\right)$, Hacienda Purisima $(9.61 \mathrm{~kg}$ $\left.\mathrm{cm}^{-2}\right)$, and Hacienda San Clemente $\left(7.11 \mathrm{~kg} \mathrm{~cm}^{-2}\right)$ showed higher strength values.

\subsection{MINERALOGIGAL AND GHEMICAL GHARACTERIZATION}

\subsubsection{ICP-MS ANALYSIS}

The metals presented in the brick samples are shown in Table 5. All studies of adobes show values of heavy metals, however, there are adobes that have high concentrations of certain heavy metals, which are described in the following paragraph. In Hacienda San Jeronimo, the resulting

Table 1. Granulometry of adobe bricks samples.

\begin{tabular}{|l|c|c|c|l|}
\hline \multicolumn{1}{|c|}{ Adobe bricks samples } & $\begin{array}{c}\text { Gravel } \\
\mathbf{( \% )}\end{array}$ & $\begin{array}{c}\text { Sand } \\
\mathbf{( \% )}\end{array}$ & $\begin{array}{c}\text { Silt-Clay } \\
\mathbf{( \% )}\end{array}$ & \multicolumn{1}{c|}{$\begin{array}{c}\text { Classification } \\
\text { (USCS) }\end{array}$} \\
\hline Hacienda San Jeronimo (XVII) & 3.43 & 23.12 & 73.45 & $\begin{array}{l}\text { MH: Inorganic silts, micaceous or diatomaceous fine sandy or } \\
\text { silty soils, elastic silts. }\end{array}$ \\
\hline Hacienda Duran (XVII) & 0.25 & 17.87 & 81.87 & $\begin{array}{l}\text { ML: Inorganic silts and very fine sands, rock flour, silty or clayey } \\
\text { fine sands or clayey silts with slight plasticity. }\end{array}$ \\
\hline Hacienda La Purisima (XVIII) & 0.83 & 14.68 & 84.49 & $\begin{array}{l}\text { ML: Inorganic silts and very fine sands, rock flour, silty or clayey } \\
\text { fine sands or clayey silts with slight plasticity. }\end{array}$ \\
\hline Hacienda San Clemente (XVII) & 2.05 & 10.01 & 87.94 & $\begin{array}{l}\text { CL: Inorganic clays of low to medium plasticity, gravelly clays, } \\
\text { sandy clays, silty clays, lean clays. }\end{array}$ \\
\hline Hacienda Rayas (XVII) & 3.95 & 22.69 & 73.36 & $\begin{array}{l}\text { ML: Inorganic silts and very fine sands, rock flour, silty or clayey } \\
\text { fine sands or clayey silts with slight plasticity. }\end{array}$ \\
\hline Hacienda Nepomuceno (XVIII) & 0.41 & 20.1 & 79.49 & $\begin{array}{l}\text { CL: Inorganic clays of low to medium plasticity, gravelly clays, } \\
\text { sandy clays, silty clays, lean clays. }\end{array}$ \\
\hline
\end{tabular}


Table 2. Natural volume weight, void ratio, porosity and real density of adobe bricks samples.

\begin{tabular}{|l|c|c|c|c|}
\multicolumn{1}{|c|}{ Adobe bricks samples } & $\begin{array}{c}\text { Natural volume weight } \\
\left(\mathbf{k g} / \mathbf{m}^{\mathbf{3}}\right)\end{array}$ & Void ratio & $\begin{array}{c}\text { Total porosity } \\
\mathbf{( \% )}\end{array}$ & $\begin{array}{c}\text { Real density } \\
\mathbf{( g / \mathbf { c m } ^ { 3 }}\end{array}$ \\
\hline Hacienda San Jeronimo (XVII) & 1015 & 1.07 & 51.64 & 2.02 \\
\hline Hacienda Duran (XVII) & 1053 & 0.98 & 49.47 & 2.05 \\
\hline Hacienda La Purisima (XVIII) & 1081 & 1.1 & 52.35 & 2.21 \\
\hline Hacienda San Clemente (XVII) & 1122 & 1.17 & 53.76 & 2.37 \\
\hline Hacienda Rayas (XVII) & 1083 & 1.03 & 50.64 & 2.15 \\
\hline Hacienda Nepomuceno (XVIII) & 1054 & 1.04 & 50.74 & 2.1 \\
\hline
\end{tabular}

Table 3. Moisture and organic material content (\%) of adobe bricks samples.

\begin{tabular}{|l|c|c|c|c|}
\hline \multicolumn{1}{c}{ Adobe bricks samples } & Wet weight (g) & $\begin{array}{c}\text { Dry weight } \\
(\mathbf{g})\end{array}$ & $\begin{array}{c}\text { Moisture content } \\
\mathbf{( \% )}\end{array}$ & $\begin{array}{c}\text { Organic material content } \\
\mathbf{( \% )}\end{array}$ \\
\hline Hacienda San Jeronimo (XVII) & 200 & 192.5 & 3.9 & 19.2 \\
\hline Hacienda Duran (XVII) & 64.32 & 63.12 & 1.9 & 5.21 \\
\hline Hacienda La Purisima (XVIII) & 54.12 & 52.75 & 2.6 & 9.15 \\
\hline Hacienda San Clemente (XVII) & 41.31 & 40.43 & 2.18 & 7.58 \\
\hline Hacienda Rayas (XVII) & 56.82 & 55.55 & 2.29 & 15.6 \\
\hline Hacienda Nepomuceno (XVIII) & 36.36 & 35.7 & 1.85 & 8.96 \\
\hline
\end{tabular}

Table 4. Simple compressive strength of adobe bricks samples.

\begin{tabular}{|l|c|c|c|c|c|}
\multicolumn{1}{|c|}{ Adobe bricks samples } & Weight & Height & Side 1 & Side 2 & $\begin{array}{c}\text { Simple compressive } \\
\text { strength }\end{array}$ \\
\hline Hacienda San Jeronimo (XVII) & $\mathbf{( g )}$ & $\mathbf{( c m )}$ & $\mathbf{( m m )}$ & $\mathbf{( m m )}$ & $\mathbf{( k g / \mathbf { c m } ^ { 2 } )}$ \\
\hline Hacienda Duran (XVII) & 697.05 & 7.92 & 8.65 & 8.71 & 5.44 \\
\hline Hacienda La Purisima (XVIII) & 674.5 & 8.16 & 8.92 & 8.7 & 5.48 \\
\hline Hacienda San Clemente (XVII) & 799 & 8.16 & 9.5 & 9.48 & 9.61 \\
\hline Hacienda Rayas (XVII) & 749.5 & 8.76 & 8.8 & 9.47 & 7.11 \\
\hline Hacienda Nepomuceno (XVIII) & 870 & 9.47 & 9.39 & 9.37 & 4.37 \\
\hline
\end{tabular}

values correspond to $\mathrm{Ni}\left(76.85 \mu \mathrm{g} \mathrm{g}^{-1}\right)$, Co $(12.10$ $\left.\mu \mathrm{g}^{-1}\right), \mathrm{Sb}\left(158.68 \mu \mathrm{g} \mathrm{g}^{-1}\right)$, and $\operatorname{Cr}\left(164.40 \mu \mathrm{g} \mathrm{g}^{-1}\right)$, respectively. In Hacienda Duran, the high values are presented in $\mathrm{Be}\left(33.78 \mu \mathrm{g} \mathrm{g}^{-1}\right)$. In Hacienda Purisima, there are the high values in $\mathrm{Sn}(2.31 \mu \mathrm{g}$ $\left.\mathrm{g}^{-1}\right)$ and $\mathrm{Th}\left(3.18 \mu \mathrm{g} \mathrm{g}^{-1}\right)$, respectively.

The Hacienda San Clemente has the high values in $\mathrm{Cu}\left(3671.18 \mu \mathrm{g} \mathrm{g}^{-1}\right), \mathrm{Zn}\left(6121.37 \mu \mathrm{g} \mathrm{g}^{-1}\right)$ and $\mathrm{Pb}\left(4347.66 \mu \mathrm{g} \mathrm{g}^{-1}\right)$. In Hacienda Rayas and Hacienda San Juan Nepomuceno, the values are low, when compared to other samples analyzed.
Heavy metal concentrations from the adobe samples display a wide range of values. Among the analyzed metals are $\mathrm{Ni}, \mathrm{Cu}, \mathrm{Co}, \mathrm{Sb}, \mathrm{Zn}, \mathrm{Pb}, \mathrm{Cr}$ and $\mathrm{V}$ showing a higher range of variability, while $\mathrm{Be}, \mathrm{Sn}$ and Th are the least variable. The selectivity sequence of metals in the adobe studied were $\mathrm{Zn}>\mathrm{Cu}>\mathrm{Pb}>\mathrm{Cr}>\mathrm{Sb}>\mathrm{Ni}>\mathrm{V}>\mathrm{Be}>\mathrm{Co}>\mathrm{Sn}>\mathrm{Th}$.

\subsubsection{XRD ANALYSIS}

The analyzed samples contain different types of crystalline minerals, such as: Quartz $\left(\mathrm{SiO}_{2}\right)$, Calcite $\left(\mathrm{CaCO}_{3}\right)$, Orthoclase $\left((\mathrm{K}, \mathrm{Ba})(\mathrm{Si}, \mathrm{Al})_{4} \mathrm{O}\right)$, 
Table 5. Chemical compositions (ICP-MS) of adobe bricks samples.

\begin{tabular}{|c|c|c|c|c|c|c|}
\hline The major and trace elements & $\begin{array}{c}\text { Hacienda San } \\
\text { Jeronimo }\end{array}$ & $\begin{array}{c}\text { Hacienda } \\
\text { Duran }\end{array}$ & $\begin{array}{c}\text { Hacienda La } \\
\text { Purisima }\end{array}$ & $\begin{array}{c}\text { Hacienda San } \\
\text { Clemente }\end{array}$ & Hacienda Rayas & $\begin{array}{c}\text { Hacienda } \\
\text { Nepomuceno }\end{array}$ \\
\hline Be $\left(\mu \mathrm{g} \mathrm{g}^{-1}\right)$ & 0.85 & 33.78 & 13.65 & 12.6 & 10.73 & 8.43 \\
\hline $\mathbf{N i}\left(\mu \mathrm{g} \mathrm{g}^{-1}\right)$ & 76.85 & 15.04 & 27.43 & 11.45 & 15.42 & 9.24 \\
\hline $\mathbf{C u}\left(\mu \mathrm{g} \mathrm{g}^{-1}\right)$ & 1160.78 & 1858.57 & 1731.99 & 3671.18 & 1078.57 & 1047.77 \\
\hline Co $\left(\mu \mathrm{g} \mathrm{g}^{-1}\right)$ & 12.1 & 6.48 & 8.88 & 4.93 & 6.12 & 4.31 \\
\hline Sn $\left(\mu \mathrm{g} \mathrm{g}^{-1}\right)$ & 1.36 & 1.47 & 2.31 & 1.71 & 2.3 & 1.87 \\
\hline $\mathbf{S b}\left(\mu \mathrm{g} \mathrm{g}^{-1}\right)$ & 158.68 & 29.95 & 89.24 & 32.24 & 44.59 & 49.38 \\
\hline $\operatorname{Zn}\left(\mu \mathrm{g} \mathrm{g}^{-1}\right)$ & 291.86 & 701.97 & 407.56 & 6121.37 & 509.64 & 576.94 \\
\hline $\mathbf{P b}\left(\mu \mathrm{g} \mathrm{g}^{-1}\right)$ & 248.34 & 575.38 & 344.74 & 4347.66 & 403.11 & 531.9 \\
\hline $\operatorname{Cr}\left(\mu g^{-1}\right)$ & 164.4 & 24.8 & 57.75 & 22.76 & 30.53 & 20.32 \\
\hline $\mathbf{V}\left(\mu \mathrm{g}^{-1}\right)$ & 63.03 & 50.33 & 74.8 & 42.67 & 55.66 & 36.99 \\
\hline Th $\left(\mu \mathrm{g} \mathrm{g}^{-1}\right)$ & 2.39 & 2.09 & 3.18 & 2.24 & 2.98 & 3.14 \\
\hline
\end{tabular}

Sanidine $\mathrm{K}\left(\mathrm{Si}_{3} \mathrm{Al}\right) \mathrm{O}_{8}$, Zircon $\mathrm{ZrSiO}_{4}$, Faujasite $\left(\mathrm{Na}_{2}, \mathrm{Ca}, \mathrm{Mg}\right)_{3.5}\left[\mathrm{Al}_{7} \mathrm{Si}_{17} \mathrm{O}_{48}\right] \cdot 32\left(\mathrm{H}_{2} \mathrm{O}\right)$, Erionite $\left(\mathrm{Na}_{2}, \mathrm{~K}_{2}, \mathrm{Ca}\right) 2 \mathrm{Al}_{4} \mathrm{Si}_{14} \mathrm{O}_{36} \cdot 15 \mathrm{H}_{2} \mathrm{O}, \quad$ Gismondine $\left(\mathrm{CaAl}_{2} \mathrm{Si}_{2} \mathrm{O}_{8} \cdot 4\left(\mathrm{H}_{2} \mathrm{O}\right)\right.$, Dickite $\left(\mathrm{Al}_{2} \mathrm{Si}_{2} \mathrm{O}_{5}(\mathrm{OH})_{4}\right.$, Illite $\left(\mathrm{K}, \mathrm{H}_{3} \mathrm{O}\right)(\mathrm{Al}, \mathrm{Mg}, \mathrm{Fe})_{2}\left(\mathrm{Si}, \mathrm{Al}_{4}\right)_{10} \mathrm{O}_{10}\left[(\mathrm{OH})_{2},\left(\mathrm{H}_{2} \mathrm{O}\right)\right]$, Schuetteite $\left(\mathrm{Hg}_{3}\left(\mathrm{SO}_{4}\right) \mathrm{O}_{2}\right)$, Sphalerite ( $\left.\mathrm{Zn}, \mathrm{Fe}\right)$ $\mathrm{S})$, Fizelyite $(\mathrm{Pb}, \mathrm{Ag})_{8} \quad \mathrm{Sb}_{11} \quad \mathrm{~S}_{24}$, Sidorenkite $\mathrm{Na}_{3} \mathrm{Mn}\left(\mathrm{PO}_{4}\right)\left(\mathrm{CO}_{3}\right)$, Sepiolite $\mathrm{Mg}_{4} \mathrm{Si}_{6} \mathrm{O}_{15}(\mathrm{OH})_{26}$ $\mathrm{H}_{2} \mathrm{O}$, Zinkenite $\mathrm{Pb}_{9} \mathrm{Sb}_{22} \mathrm{~S}_{42}$, Brushite $\mathrm{CaPO}_{3}$ $(\mathrm{OH})_{2} \mathrm{H}_{2} \mathrm{O}$ and gypsum $\left(\mathrm{CaSO}_{4} \cdot 2 \mathrm{H}_{2} \mathrm{O}\right)$ (Table 6 and Figure 5).

\subsubsection{SEM-EDS ANALYSIS}

The SEM examination revealed silicon/aluminum $(\mathrm{Si} / \mathrm{Al})$-rich particles and $\mathrm{C}, \mathrm{Ca}, \mathrm{Na}, \mathrm{Mg}, \mathrm{K}$, and $\mathrm{P}$ in all adobe bricks. The presences of pollen, dry grass and vegetal fibers are common in almost all the studied adobes, excepting those that belong to the Hacienda La Purisima. As for the metals, it can be observed that most of the adobes of the haciendas studied have Fe, $\mathrm{Cu}, \mathrm{Hg}$, Sn, Zn, S, and Se. Hacienda San Clemente is the only one that, in addition to presenting the aforementioned metals, presents $\mathrm{Pb}$ (Figures 6, 7 and 8).

\section{Discussion and conclusions}

Adobe bricks are one of the oldest and most commonly used materials in construction. The use of adobe is very common in Latin America,
Africa, the Indian subcontinent and other parts of Asia, the Middle East and Southern Europe. The results of the present study indicate that the adobe bricks of the seventeenth and eighteenth-century buildings in Guanajuato city are texturally similar. The analysis of particle size indicates that sizes, silt and clay are the predominant component in the matrix of the adobes studied, the percentages of clay are high, exceeding $87 \%$ (Table 1); the fact that fractions of fine, very fine and slime sands are dominant, with a moderate amount of organic matter (Table 3), which gives these materials high erodibility and a potential risk to be eroded by water, especially in the rainiest areas. Taking into account the degree of consolidation and compaction of presenting the adobes attenuates this risk, if only for a while. Finally, the similarity of these materials in their distribution and particle size (Figure 1) suggests that there was a careful selection of raw materials for the production of adobes and control in production. Similarly, we can see that the buildings of the seventeenth century have greater particle size diversity, and according to the USCS, they correspond to three types of soil: MH, ML and CL, while the eighteenth-century ones correspond to two types of soil: ML and CL, and $\mathrm{XX}^{\text {th }}$-century buildings are the type of soil: $\mathrm{ML}$ (Table 1).

Different values of compression of the samples are explained by the different percentage content in clays and silts. The Hacienda Rayas of the 
Table 6. Chemical compositions (XRD) of adobe samples.

\begin{tabular}{|c|c|c|c|c|c|c|c|}
\hline $\begin{array}{c}\text { Adobe bricks } \\
\text { Samples }\end{array}$ & Tectosilicates & Phyllosilicates & Nesosilicates & Carbonates & Sulfides & Sulfates & Phosphates \\
\hline Hacienda San Jeronimo (XVII) & $\begin{array}{l}\text { Quartz, Faujasite- } \\
\mathrm{Na}\end{array}$ & ------- & ----- & Calcite & Sphalerite & ---------- & Sidorenkite \\
\hline Hacienda Duran (XVII) & $\begin{array}{l}\text { Quartz, Faujasite- } \\
\mathrm{K}, \quad \text { Faujasite-Na, } \\
\text { Erionite-K }\end{array}$ & Dickite & ----- & ---- & Fizelyite & Gypsum & Brushite \\
\hline Hacienda La Purisima (XVIII) & $\begin{array}{l}\text { Quartz, Orthoclase, } \\
\text { Sanidine, Faujasite } \\
\mathrm{Na} \text {, Gismondine }\end{array}$ & ---- & ----- & Calcite & Sphalerite & Schuetteite & ------- \\
\hline Hacienda San Clemente (XVII) & $\begin{array}{l}\text { Quartz, Faujasite- } \\
\mathrm{Na}\end{array}$ & ----- & ----- & Calcite & Zinkenite & $\begin{array}{l}\text { Gypsum, } \\
\text { Schuetteite }\end{array}$ & ----------- \\
\hline Hacienda Rayas (XVII) & $\begin{array}{l}\text { Quartz, Orthoclase, } \\
\text { Faujasite-Na, } \\
\text { Erionite-K, } \\
\text { Gismondine }\end{array}$ & $\begin{array}{l}\text { Dickite, } \\
\text { Sepiolite Illite }\end{array}$ & ----- & Calcite & & Schuetteite & \\
\hline Hacienda Nepomuceno (XVIII) & $\begin{array}{l}\text { Quartz, } \\
\text { Gismondine }\end{array}$ & ------ & Zircon & Calcite & Sphalerite & Gypsum & ----- \\
\hline
\end{tabular}

seventeenth century has a greater resistance to uniaxial compression, followed by the Hacienda La Purisima of the eighteenth century and San Clemente of the seventeenth century (Table 4). All samples contain greater amount of aluminum and silicon, have a higher content of silty clays, for example the Hacienda San Clemente (XVII) and Hacienda La Purisima (XVIII). Calcium is a natural consolidator on earth, which means an advantage in the raw material used for the construction of the haciendas; this is the case of the Hacienda La Purisima (XVIII). Porosity results are related to the use of vegetable fibers as a supplement in the mixture of soil and water. According to the percentages of porosity obtained (Table 2), the samples studied of the Hacienda San Clemente (XVII) with a 53.76\% has the highest porosity, followed by the Hacienda La Purisima (XVIII) with a $52.35 \%$. Macro porosity can justify the current good condition of the adobes. The results of density of all samples tested have no significant changes. However, in the Hacienda San
Clemente the above average between 1.6 and $2.2 \mathrm{~g} / \mathrm{cm}^{3}$ was reported by Achenza and Sanna (2006). Organic matter plays an important role in the above variables (porosity and density); as in a sample with high content of organic matter, it increases the porosity and aeration capacity of clayey soils, better tolerating the mechanical effects caused by time. Based on this, the adobes of seventeenth-century haciendas (San Jeronimo and Rayas) have higher content of organic matter, which explains its percentage of porosity and resistance to uniaxial compression. All adobes studied have pollen, grass, and plant fibers. Mix dry grass with clay allows proper agglutination, great weather ability and prevents the blocks once solidified from cracking. The presence of these elements provides insight into the construction history of the building. Another important aspect is the adobe dimensions; normally, they are ratios of $1: 2$ between the width and the length, varying in thickness between 6 and $10 \mathrm{~cm}$. These, measures allow for proper drying. The most common 

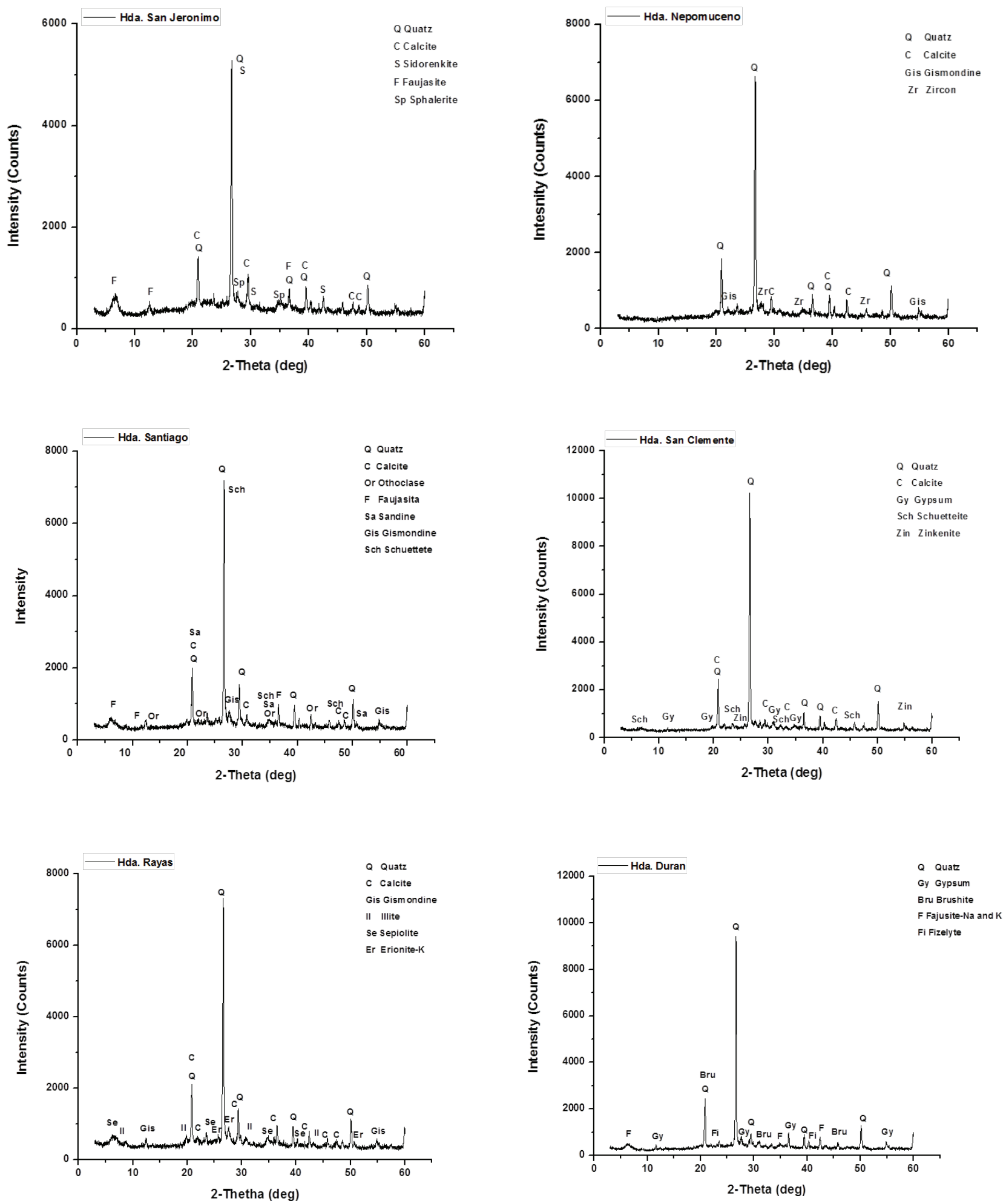

XRD of adobe bricks samples. 
a

001
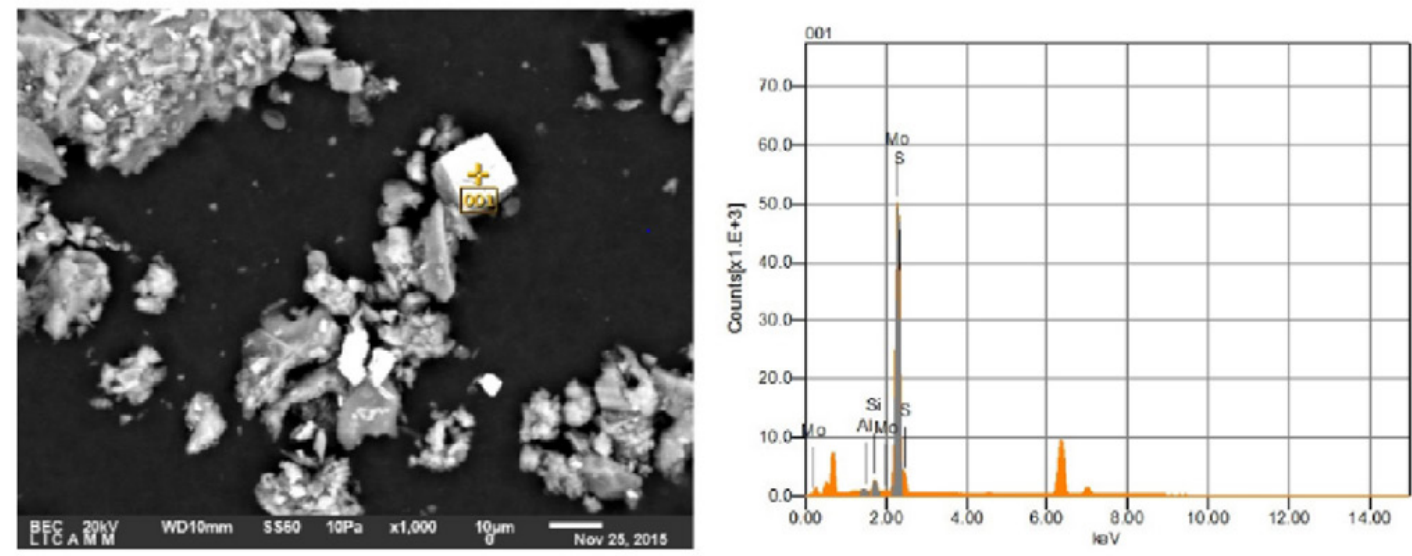

Volt

$: 20.00 \mathrm{kV}$

Acquisition

Condition

Formula

mass\% Atom\% Sigma

Net

K ratio

$: \times 1,000$

Instrument

6010LA

Al $\quad 0.25$

0.52

10336

0.0055424

Date : :2015/11/25

Current

$:-\ldots$

Process Time : : T3

Si $\quad 1.57$

33.43

3.14

70953

0.0425881

Live Time

: $50.00 \mathrm{sec}$

Mo

64.75

58.48

1488511

1.0781689

Real Time

$56.59 \mathrm{sec}$

Total

100.00

1000

DeadTime $\quad: 12.00 \%$

Count Rate $\quad: 22574.00$ CPS

b

002
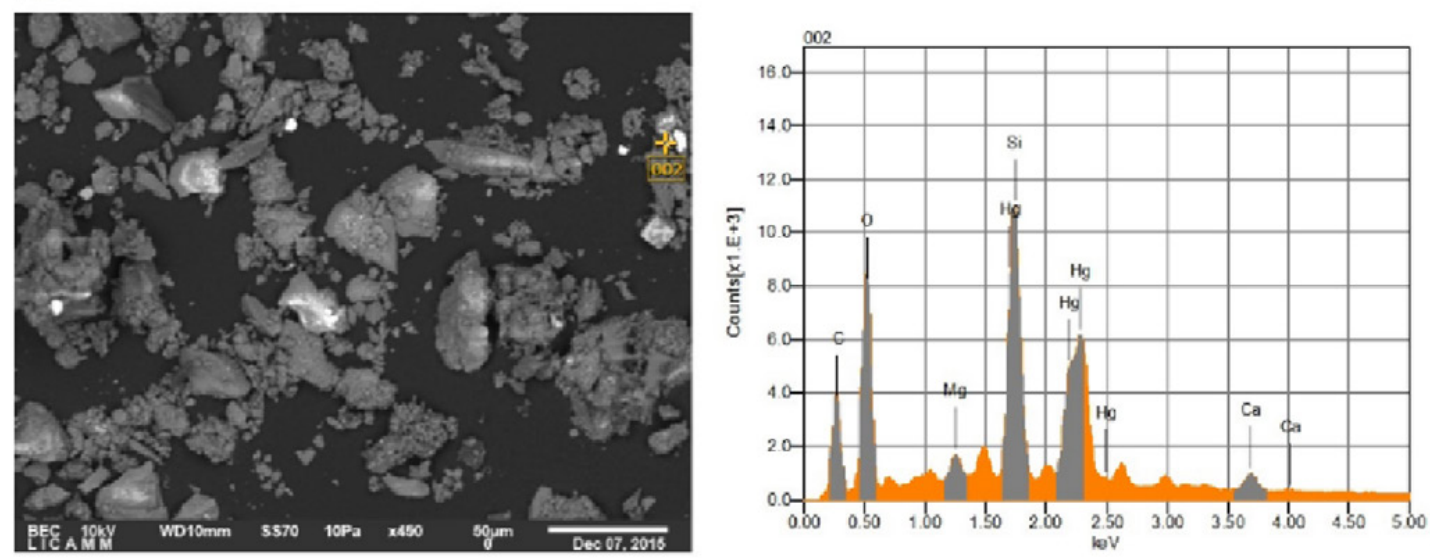

Volt $\quad: 10.00 \mathrm{kV}$

Mag. : $\times 450$

Date :2015/12/07

Pixel $: 640 \times 480$

$\begin{array}{lll}\text { Acquisition } & \text { Condition } & \text { Formula } \\ \text { Instrument } & : 6010 \mathrm{LA} & \mathrm{C} \\ \text { Volt } & : 10.00 \mathrm{kV} & \mathrm{O} \\ \text { Current } & :-- & \mathrm{Mg} \\ \text { Process Time } & : \mathrm{T} 1 & \mathrm{Si} \\ \text { Live Time } & : 30.00 \mathrm{sec} . & \mathrm{Ca} \\ \text { Real Time } & : 31.32 \mathrm{sec} . & \mathrm{Hg} \\ \text { DeadTime } & : 4.00 \% & \text { Total } \\ \text { Count Rate } & : 20989.00 \mathrm{CPS} & \end{array}$

$\begin{array}{llllll}\text { mass\% } & \text { Atom\% } & \text { Sigma } & \text { Net } & \text { K ratio } & \text { Line } \\ 18.48 & 40.52 & 0.02 & 77941 & 0.0625248 & \mathrm{~K} \\ 20.58 & 33.88 & 0.05 & 173311 & 0.4089363 & \mathrm{~K} \\ 1.53 & 1.65 & 0.02 & 30480 & 0.0654484 & \mathrm{~K} \\ 17.01 & 15.95 & 0.07 & 321331 & 0.8811359 & \mathrm{~K} \\ 4.63 & 3.04 & 0.07 & 32854 & 0.2547004 & \mathrm{~K} \\ 37.78 & 4.96 & 0.23 & 239711 & 1.2448987 & \mathrm{M} \\ 100.00 & 100.00 & & & & \end{array}$

Figure 6 SEM microphotographs of heavy metals and EDS composition: a, b) Mining Hacienda Duran; c, d) Mining Hacienda San Juan Nepomuceno. 
C
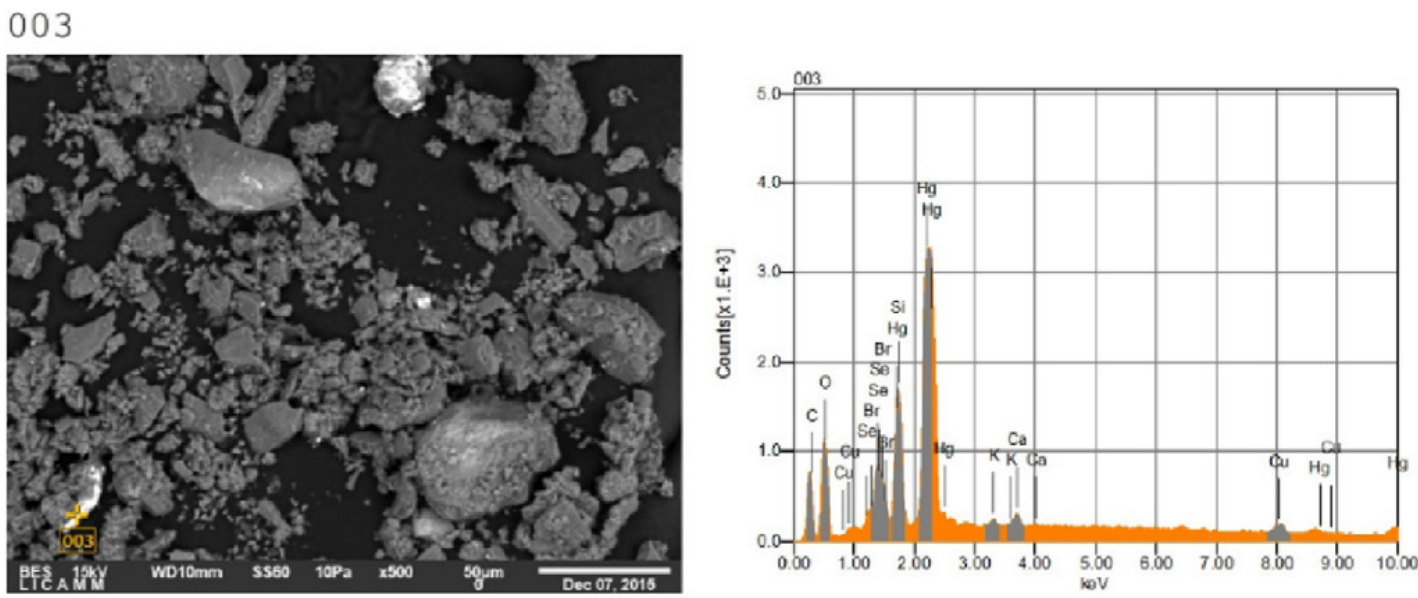

$\begin{array}{llll}\text { Volt } & : 15.00 \mathrm{kV} & \text { Acquisition } & \text { Condition } \\ \text { Mag. } & : \times 500 & \text { Instrument } & : 6010 \mathrm{LA} \\ \text { Date } & : 2015 / 12 / 07 & \text { Volt } & : 15.00 \mathrm{KV} \\ \text { Pixel } & : 640 \times 480 & \text { Current } & :-- \\ & & \text { Process Time } & : \text { T1 } \\ & & \text { Live Time } & : 30.00 \mathrm{sec} . \\ & & \text { Real Time } & : 30.55 \mathrm{sec} . \\ & & \text { DeadTime } & : 2.00 \% \\ & & \text { Count Rate } & : 8822.00 \mathrm{CPS}\end{array}$

$\begin{array}{lllllll}\text { Formula } & \text { mass\% } & \text { Atom\% } & \text { Sigma } & \text { Net } & \text { K ratio } & \text { Line } \\ \mathrm{C} & 14.92 & 48.04 & 0.03 & 15522 & 0.0113790 & \mathrm{~K} \\ \mathrm{O} & 10.26 & 24.79 & 0.06 & 23401 & 0.0562231 & \mathrm{~K} \\ \mathrm{Si} & 4.43 & 6.10 & 0.06 & 41830 & 0.0600425 & \mathrm{~K} \\ \mathrm{~K} & 0.68 & 0.67 & 0.04 & 3878 & 0.0101309 & \mathrm{~K} \\ \mathrm{Ca} & 1.30 & 1.26 & 0.05 & 7272 & 0.0216176 & \mathrm{~K} \\ \mathrm{Cu} & 7.13 & 4.34 & 0.22 & 7140 & 0.1218169 & \mathrm{~K} \\ \mathrm{Se} & 4.47 & 2.19 & 0.11 & 23134 & 0.0639179 & \mathrm{~L} \\ \mathrm{Br} & 5.70 & 2.76 & 0.22 & 15439 & 0.0704162 & \mathrm{~L} \\ \mathrm{Hg} & 51.11 & 9.85 & 0.28 & 193609 & 0.6161987 & \mathrm{M} \\ \text { Total } & 100.00 & 100.00 & & & & \end{array}$

d

004
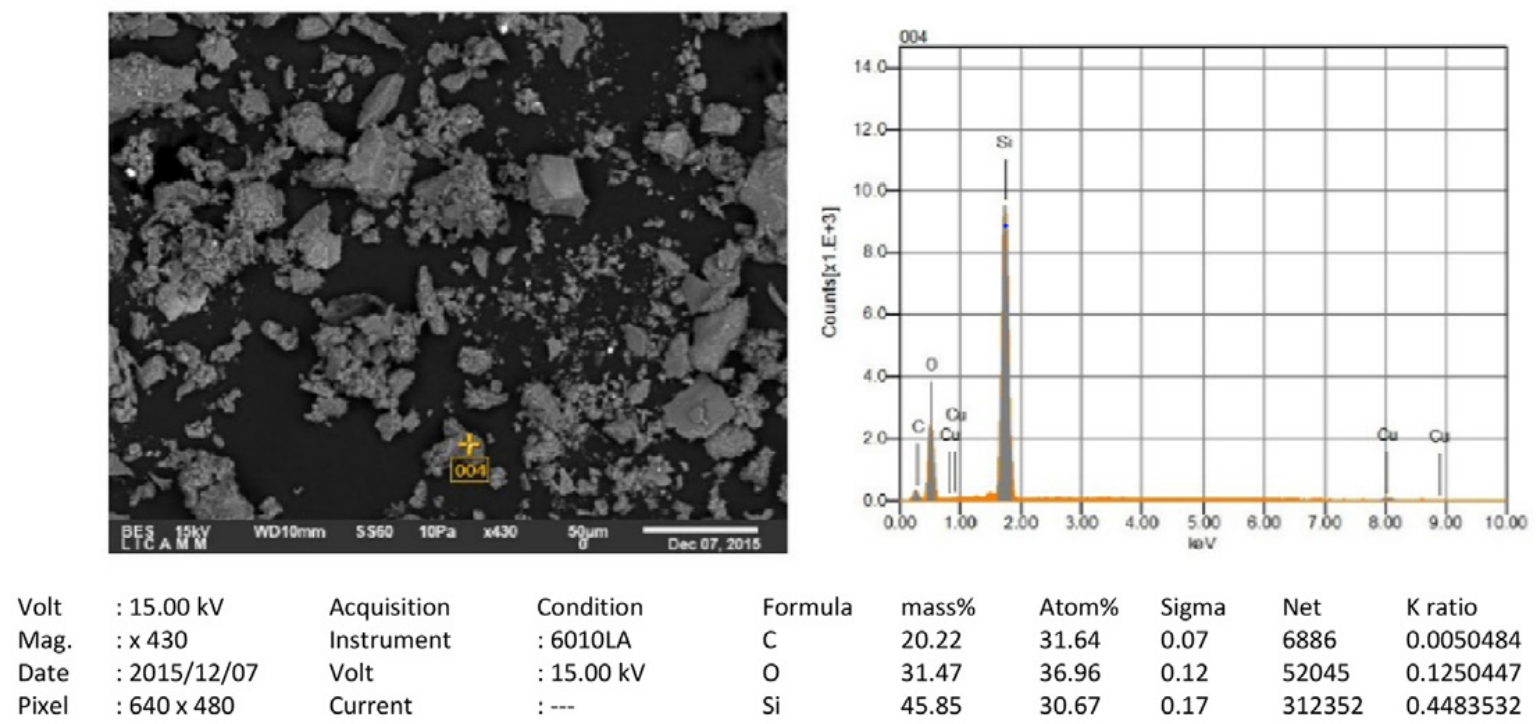

$\begin{array}{lll}\text { Acquisition } & \text { Condition } & \text { Form } \\ \text { Instrument } & : 6010 \mathrm{LA} & \mathrm{C} \\ \text { Volt } & : 15.00 \mathrm{kV} & \mathrm{O} \\ \text { Current } & :-- & \mathrm{Si} \\ \text { Process Time } & : \text { T1 } & \mathrm{Cu} \\ \text { Live Time } & : 30.00 \mathrm{sec} . & \text { Tota } \\ \text { Real Time } & : 30.41 \mathrm{sec} . & \\ \text { DeadTime } & : 2 \_00 \% & \\ \text { Count Rate } & : 5780.00 \mathrm{CPS}\end{array}$

$\begin{array}{lllllll}\text { Formula } & \text { mass\% } & \text { Atom\% } & \text { Sigma } & \text { Net } & \text { K ratio } & \text { Line } \\ \mathrm{C} & 20.22 & 31.64 & 0.07 & 6886 & 0.0050484 & \mathrm{~K} \\ \mathrm{O} & 31.47 & 36.96 & 0.12 & 52045 & 0.1250447 & \mathrm{~K} \\ \mathrm{Si} & 45.85 & 30.67 & 0.17 & 312352 & 0.4483532 & \mathrm{~K} \\ \mathrm{Cu} & 2.45 & 0.72 & 0.17 & 1280 & 0.0218356 & \mathrm{~K} \\ \text { Total } & 100.00 & 100.00 & & & & \\ & & & & & & \end{array}$

Figure 6 (Continuation) SEM microphotographs of heavy metals and EDS composition: a, b) Mining Hacienda Duran; c, d) Mining Hacienda San Juan Nepomuceno. 
ratios found are $6 \times 15 \times 30 \mathrm{~cm}, 10 \times 30 \times 60 \mathrm{~cm}$ and $7 \times 20 \times 40 \mathrm{~cm}$. In our case study, the bricks that make up the buildings studied have different dimensions, seventeenth-century sizes are $12 \times 35$ x $45 \mathrm{~cm}$, while the eighteenth-century sizes are $12 \times 40 \times 60 \mathrm{~cm}$. This indicates that each owner of the haciendas had his own technique for the preparation of the adobes. ICP-MS shows that adobe bricks share the same heavy metals $(\mathrm{Cu}$, $\mathrm{Zn}, \mathrm{Be}, \mathrm{Sn}, \mathrm{Pb}, \mathrm{Ni}, \mathrm{Co}, \mathrm{V}, \mathrm{Sb}, \mathrm{Hg}$, and Cr), but with different concentrations. This indicates that the origin of the raw materials used for the manufacture of adobes is local, that is, the benefit derived from the mining of the time. Heavy metal concentrations from the adobe samples display a wide range of values. The $\mathrm{Ni}, \mathrm{Cu}, \mathrm{Co}, \mathrm{Sb}, \mathrm{Zn}, \mathrm{Pb}$, $\mathrm{Cr}$ and $\mathrm{V}$ show a higher range of variability, while $\mathrm{Be}, \mathrm{Sn}$ and Th are the least variable. The selectivity sequence of metals in the adobe studied were $\mathrm{Zn}>\mathrm{Cu}>\mathrm{Pb}>\mathrm{Cr}>\mathrm{Sb}>\mathrm{Ni}>\mathrm{V}>\mathrm{Be}>\mathrm{Co}>\mathrm{Sn}>\mathrm{Th}$.
The results obtained from the X-ray diffraction show the presence of 18 major minerals: Quartz, Orthoclase, Calcite, Faujasite $\mathrm{Na}$ and K, Erionite-K, Gismondine, Illite, Dickite, Schuetteite, Sphalerite, Zinkenite, Sanidine, Sidorenkite, Zircon, Sepiolite, Brushite, Fizelyte and Gypsum. Quartz and Calcite are the major minerals.

The presence of Quartz $\left(\mathrm{SiO}_{2}\right)$ is attributed to the waste generated after the beneficiation process, and to the use of some sand particles as an additive material in brick manufacturing. Calcite is the result of the addition of sodium carbonate and calcite during the mineral beneficiation process by the amalgamation method. The presence of Schuetteite $\left(\mathrm{Hg}_{3}\left(\mathrm{SO}_{4}\right) \mathrm{O}_{2}\right)$, Sphalerite $(\mathrm{Zn}, \mathrm{Fe})$ $\mathrm{S})$ and Zinkenite $\left(\mathrm{Pb}_{9} \mathrm{Sb}_{22} \mathrm{~S}_{42}\right)$ is due to the process used during the seventeenth and eighteenth centuries. An important element within the adobes is the presence of Erionite- $\mathrm{K}$. The Erionite-K,

a

\section{5}

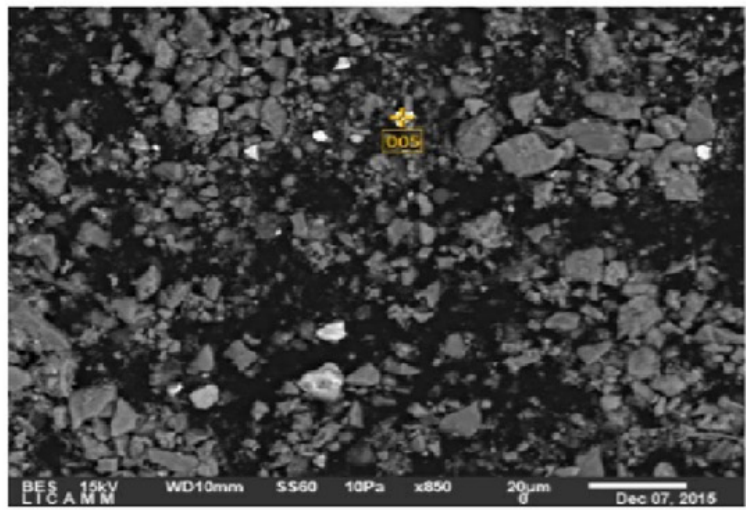

$\begin{array}{ll}\text { Volt } & : 15.00 \mathrm{kV} \\ \text { Mag. } & : \times 850 \\ \text { Date } & : 2015 / 12 / 07 \\ \text { Pixel } & : 640 \times 480\end{array}$

$\begin{array}{ll}\text { Acquisition } & \text { Condition } \\ \text { Instrument } & : 6010 \mathrm{LA} \\ \text { Volt } & : 15.00 \mathrm{kV} \\ \text { Current } & :-- \\ \text { Process Time } & : \text { T1 } \\ \text { Live Time } & : 30.00 \mathrm{sec} . \\ \text { Real Time } & : 30.91 \mathrm{sec} . \\ \text { DeadTime } & : 3.00 \% \\ \text { Count Rate } & : 14183.00 \mathrm{CPS}\end{array}$

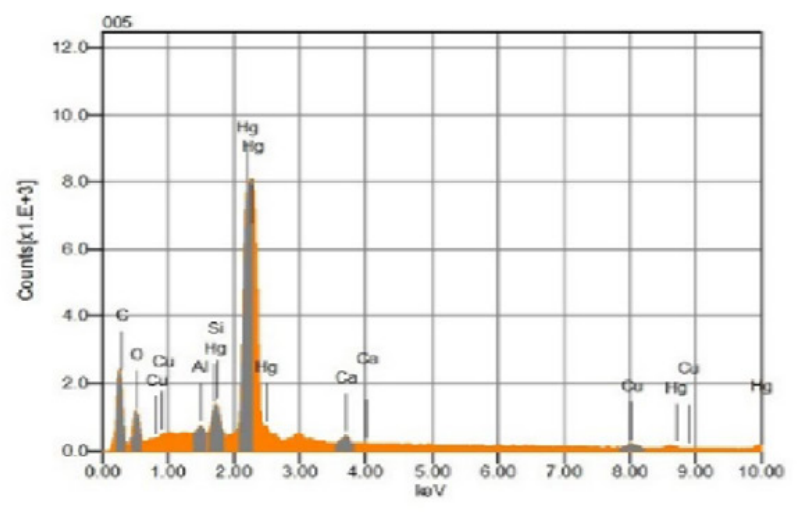

$\begin{array}{lllllll}\text { Formula } & \text { mass\% } & \text { Atom\% } & \text { Sigma } & \text { Net } & \text { K ratio } & \text { Line } \\ \mathrm{C} & 21.58 & 68.70 & 0.03 & 47514 & 0.0348325 & \mathrm{~K} \\ \mathrm{O} & 5.47 & 13.08 & 0.04 & 19535 & 0.0348325 & \mathrm{~K} \\ \mathrm{Al} & 0.42 & 0.59 & 0.02 & 6985 & 0.0469047 & \mathrm{~K} \\ \mathrm{Si} & 0.88 & 1.20 & 0.03 & 15422 & 0.0089853 & \mathrm{~K} \\ \mathrm{Ca} & 1.26 & 1.20 & 0.04 & 11781 & 0.0221373 & \mathrm{~K} \\ \mathrm{Cu} & 4.41 & 2.65 & 0.13 & 7564 & 0.1290525 & \mathrm{~K} \\ \mathrm{Hg} & 65.99 & 12.58 & 0.24 & 462915 & 1.4733177 & \mathrm{M}\end{array}$

Figure 7 SEM microphotographs of heavy metals and EDS composition: a, b) Mining Hacienda Duran; c, d) Mining Hacienda San Juan Nepomuceno. 
b
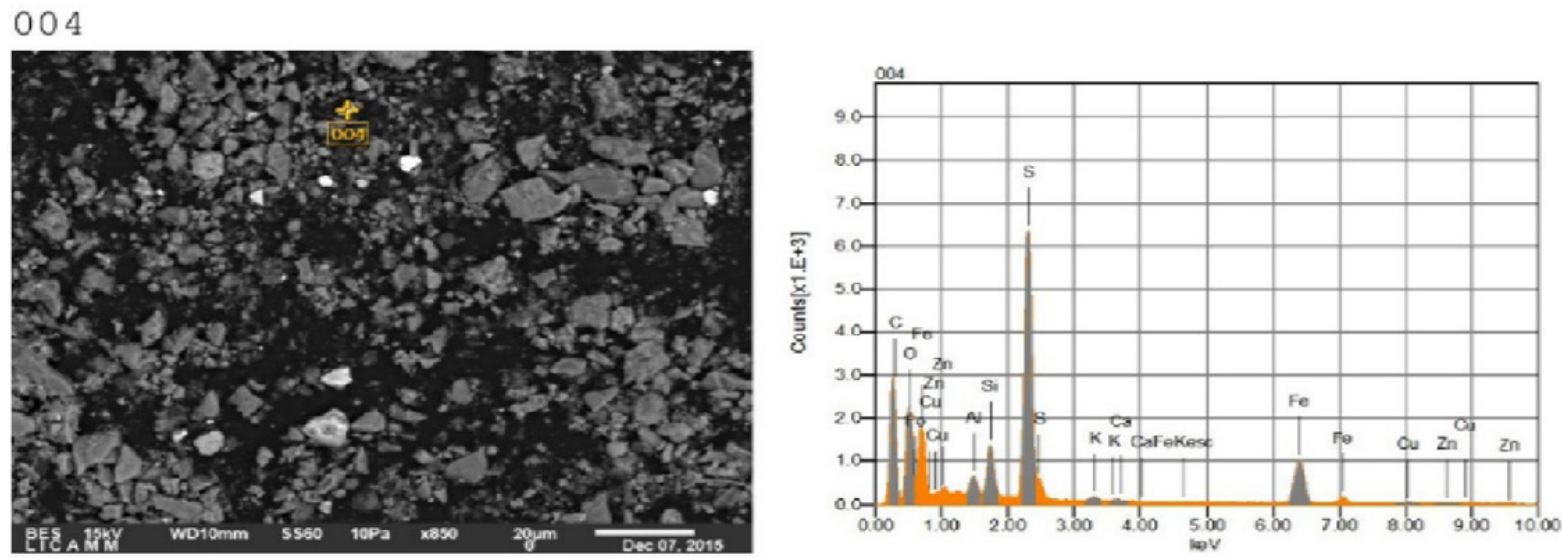

$\begin{array}{llll}\text { Volt } & : 15.00 \mathrm{kV} & \text { Acquisition } & \text { Condition } \\ \text { Mag. } & : \times 850 & \text { Instrument } & : 6010 \mathrm{LA} \\ \text { Date } & : 2015 / 12 / 07 & \text { Volt } & : 15.00 \mathrm{kV} \\ \text { Pixel } & : 640 \times 480 & \text { Current } & :-- \\ & & \text { Process Time } & : \text { T1 } \\ & & \text { Live Time } & : 30.00 \mathrm{sec} . \\ & & \text { Real Time } & : 30.32 \mathrm{sec} . \\ & & \text { DeadTime } & : 2.00 \% \\ & & \text { Count Rate } & : 8467.00 \mathrm{CPS}\end{array}$

$\begin{array}{lllllll}\text { Formula } & \text { mass\% } & \text { Atom\% } & \text { Sigma } & \text { Net } & \text { K ratio } & \text { Line } \\ \mathrm{C} & 44.33 & 66.67 & 0.05 & 62075 & 0.0455077 & \mathrm{~K} \\ \mathrm{O} & 13.04 & 14.73 & 0.06 & 46221 & 0.1110513 & \mathrm{~K} \\ \mathrm{Al} & 0.77 & 0.52 & 0.02 & 12724 & 0.0163671 & \mathrm{~K} \\ \mathrm{Si} & 2.15 & 1.39 & 0.03 & 37381 & 0.0536573 & \mathrm{~K} \\ \mathrm{~S} & 16.25 & 9.15 & 0.04 & 259195 & 0.4437159 & \mathrm{~K} \\ \mathrm{~K} & 0.45 & 0.21 & 0.02 & 4929 & 0.0128785 & \mathrm{~K} \\ \mathrm{Ca} & 0.15 & 0.07 & 0.02 & 1552 & 0.0046130 & \mathrm{~K} \\ \mathrm{Fe} & 20.05 & 6.49 & 0.10 & 67221 & 0.5433379 & \mathrm{~K} \\ \mathrm{Cu} & 1.43 & 0.41 & 0.08 & 2137 & 0.0364660 & \mathrm{~K} \\ \mathrm{Sn} & 1.37 & 0.38 & 0.09 & 1715 & 0.0347066 & \mathrm{~K} \\ \text { Total } & 100.00 & 100.00 & & & & \end{array}$

C
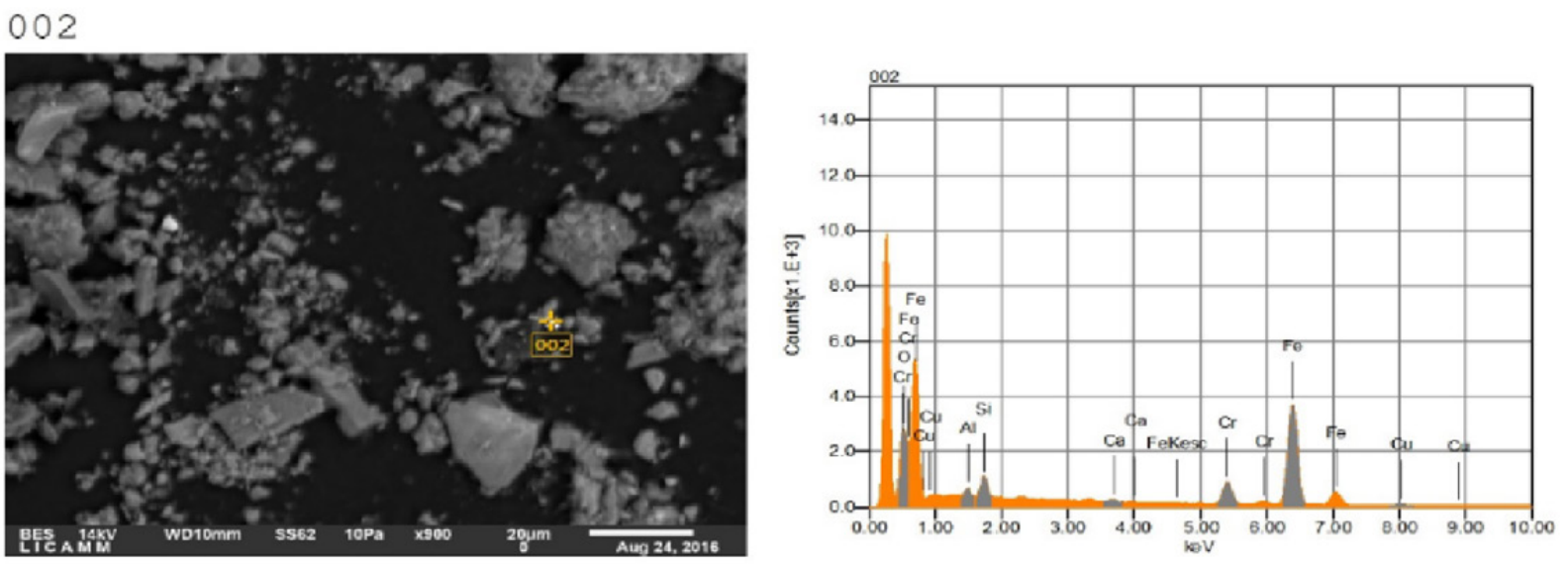

\begin{tabular}{|c|c|c|c|c|c|c|c|c|c|c|}
\hline Volt & $: 14.00 \mathrm{kV}$ & Acquisition & Condition & Formula & mass $\%$ & Atom $\%$ & Sigma & Net & $\mathrm{K}$ ratio & Line \\
\hline Mag. & $: \times 900$ & Instrument & $:$ 6010LA & C & 39.49 & 71.91 & 0.02 & 200760 & 0.0490592 & $\mathrm{~K}$ \\
\hline Date & : 2016/08/24 & Volt & $: 14.00 \mathrm{kV}$ & $\mathrm{O}$ & 3.92 & 5.36 & 0.03 & 35591 & 0.0285039 & K \\
\hline \multirow[t]{7}{*}{ Pixel } & $: 1280$ x 960 & Current & :-- & Al & 0.32 & 0.26 & 0.01 & 8130 & 0.0034859 & $\mathrm{~K}$ \\
\hline & & Process Time & $: \mathrm{T} 1$ & Si & 0.86 & 0.67 & 0.02 & 23434 & 0.0112123 & $\mathrm{~K}$ \\
\hline & & Live Time & : $90.00 \mathrm{sec}$ & $\mathrm{Ca}$ & 0.21 & 0.11 & 0.02 & 3793 & 0.0037585 & K \\
\hline & & Real Time & : $90.84 \mathrm{sec}$ & $\mathrm{Cr}$ & 5.48 & 2.30 & 0.04 & 49665 & 0.0911921 & K \\
\hline & & DeadTime & $: 1.00 \%$ & $\mathrm{Fe}$ & 47.83 & 18.73 & 0.11 & 254134 & 0.6847137 & K \\
\hline & & Count Rate & $: 4005.00$ & $\mathrm{Cu}$ & 1.90 & 0.65 & 0.07 & 4142 & 0.0235566 & $\mathrm{~K}$ \\
\hline & & & CPS & Total & 100.00 & 100.00 & & & & \\
\hline
\end{tabular}

Figure 7 (Continuation) SEM microphotographs of heavy metals and EDS composition: a, b) Mining Hacienda Duran; c, d) Mining Hacienda San Juan Nepomuceno. 
d
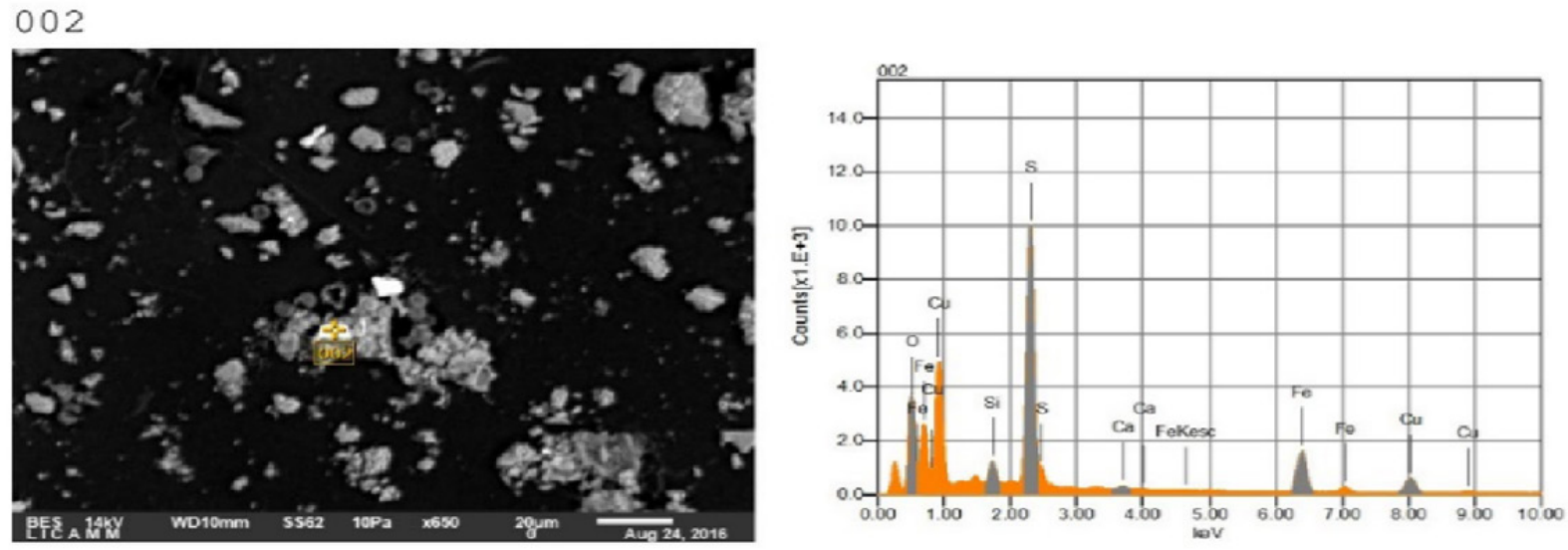

$\begin{array}{lllll}\text { Volt } & : 14.00 \mathrm{kV} & \text { Acquisition } & \text { Condition } & \text { Formula } \\ \text { Mag. } & : \times 650 & \text { Instrument } & : 6010 \mathrm{LA} & \mathrm{C} \\ \text { Date } & : 2016 / 08 / 24 & \text { Volt } & : 14.00 \mathrm{kV} & \mathrm{O} \\ \text { Pixel } & : 640 \times 480 & \text { Current } & :-- & \mathrm{Si} \\ & & \text { Process Time } & : \mathrm{T} 1 & \mathrm{~S} \\ & & \text { Live Time } & : 90.00 \mathrm{sec} . & \mathrm{Ca} \\ & & \text { Real Time } & : 90.98 \mathrm{sec} . & \mathrm{Fe} \\ & & \text { DeadTime } & : 1 \% & \mathrm{Cu} \\ & & \text { Count Rate } & : 5175,00 & \text { Total } \\ & & \text { CPS } & \end{array}$

$\begin{array}{llllll}\text { mass\% } & \text { Atom\% } & \text { Sigma } & \text { Net } & \text { K ratio } & \text { Line } \\ 14.86 & 35.64 & 0.03 & 22742 & 0.0055575 & \mathrm{~K} \\ 10.25 & 18.44 & 0.04 & 71392 & 0.0571757 & \mathrm{~K} \\ 1.44 & 1.48 & 0.02 & 28246 & 0.0135148 & \mathrm{~K} \\ 21.14 & 18.98 & 0.05 & 400345 & 0.2284499 & \mathrm{~K} \\ 0.43 & 0.31 & 0.02 & 5550 & 0.0054993 & \mathrm{~K} \\ 26.22 & 13.52 & 0.10 & 105299 & 0.2837078 & \mathrm{~K} \\ 25.66 & 11.63 & 0.19 & 42015 & 0.2389432 & \mathrm{~K} \\ 100.00 & 100.00 & & & & \end{array}$

e

001
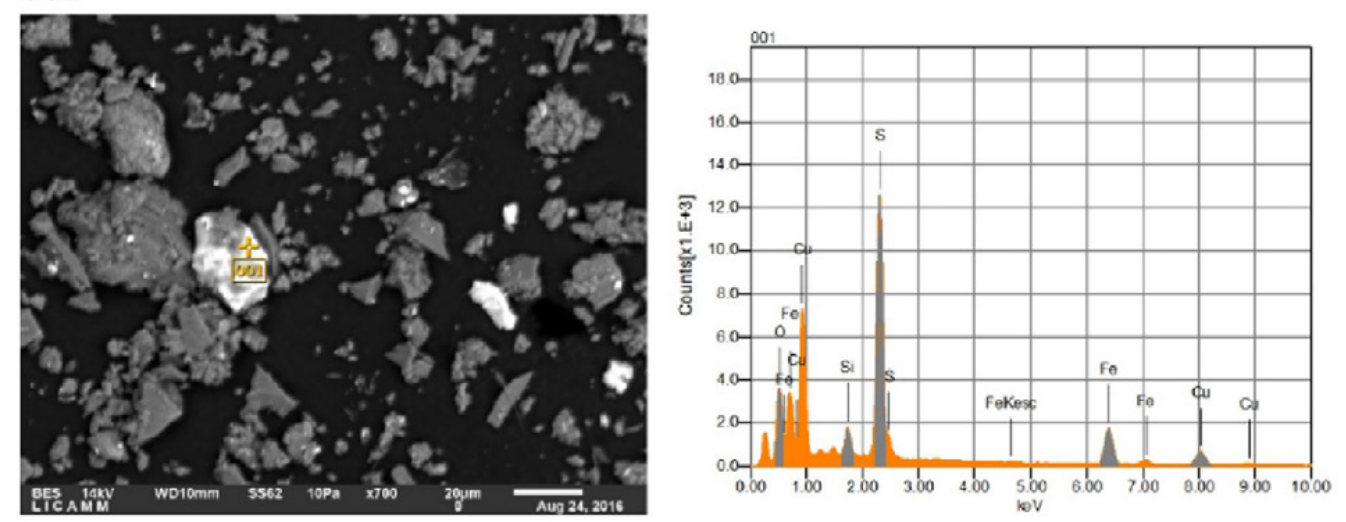

$\begin{array}{lllll}\text { Volt } & : 14.00 \mathrm{kV} & \text { Acquisition } & \text { Condition } & \text { Formula } \\ \text { Mag. } & : \times 700 & \text { Instrument } & : 6010 \mathrm{LA} & \mathrm{C} \\ \text { Date } & : 2016 / 08 / 24 & \text { Volt } & : 14.00 \mathrm{kV} & \mathrm{O} \\ \text { Pixel } & : 1280 \times 960 & \text { Current } & :-- & \mathrm{Si} \\ & & \text { Process Time } & : \text { T1 } & \mathrm{S} \\ & & \text { Live Time } & : 90.00 \mathrm{sec} . & \mathrm{Fe} \\ & & \text { Real Time } & : 91.21 \mathrm{sec} . & \mathrm{Cu} \\ & & \text { DeadTime } & : 1 \% & \text { Total } \\ & & \text { Count Rate } & : 6242.00 \mathrm{CPS} & \end{array}$

$\begin{array}{llllll}\text { mass } \% & \text { Atom\% } & \text { Sigma } & \text { Net } & \text { K ratio } & \text { Line } \\ 16.20 & 38.40 & 0.03 & 27470 & 0.0067128 & \mathrm{~K} \\ 8.72 & 15.52 & 0.04 & 68417 & 0.0547931 & \mathrm{~K} \\ 1.79 & 1.82 & 0.02 & 40900 & 0.0195692 & \mathrm{~K} \\ 22.60 & 20.06 & 0.05 & 496617 & 0.2833856 & \mathrm{~K} \\ 24.53 & 12.50 & 0.09 & 114147 & 0.3075477 & \mathrm{~K} \\ 26.15 & 11.71 & 0.18 & 49608 & 0.2821230 & \mathrm{~K} \\ 100.00 & 100.00 & & & & \end{array}$

Figure 7 (Continuation) SEM microphotographs of heavy metals and EDS composition: a, b) Mining Hacienda Duran; c, d) Mining Hacienda San Juan Nepomuceno. 


\section{4}

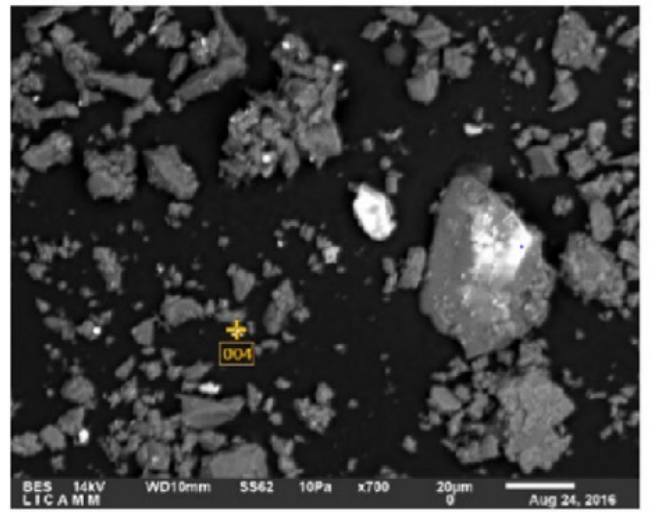

$\begin{array}{lllll}\text { Volt } & : 14.00 \mathrm{kV} & \text { Acquisition } & \text { Condition } & \text { Formula } \\ \text { Mag. } & : \times 700 & \text { Instrument } & : 6010 \mathrm{LA} & \mathrm{C} \\ \text { Date } & : 2016 / 08 / 24 & \text { Volt } & : 14.00 \mathrm{kV} & \mathrm{O} \\ \text { Pixel } & : 1280 \times 960 & \text { Current } & :--- & \mathrm{Si} \\ & & \text { Process Time } & : \mathrm{T} 1 & \mathrm{Cu} \\ & & \text { Live Time } & : 90.00 \mathrm{sec} . & \mathrm{Hg} \\ & & \text { Real Time } & : 91.00 \mathrm{sec} . & \text { Total } \\ & & \text { DeadTime } & : 1 \% & \\ & & \text { Count Rate } & : 4977.00 \mathrm{CPS} & \end{array}$

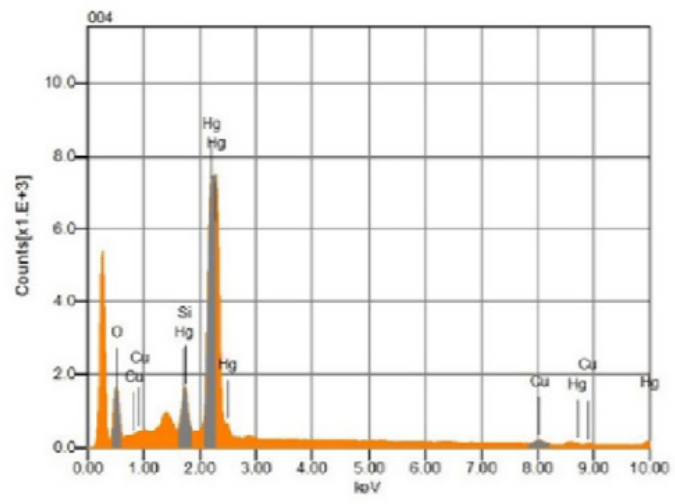

$\begin{array}{llllll}\text { mass } \% & \text { Atom\% } & \text { Sigma } & \text { Net } & \text { K ratio } & \text { Line } \\ 34.40 & 78.10 & 0.03 & 108467 & 0.0265058 & \mathrm{~K} \\ 6.78 & 11.56 & 0.04 & 30114 & 0.0241174 & \mathrm{~K} \\ 1.28 & 1.24 & 0.03 & 27513 & 0.0131640 & \mathrm{~K} \\ 4.37 & 1.88 & 0.13 & 7230 & 0.0411186 & \mathrm{~K} \\ 53.17 & 7.23 & 0.20 & 440029 & 0.4668257 & \mathrm{M}\end{array}$

$100.00 \quad 100.00$

Figure 7 (Continuation) SEM microphotographs of heavy metals and EDS composition: a, b) Mining Hacienda Duran; c, d) Mining Hacienda San Juan Nepomuceno.

which is a natural fibrous Zeolite found in certain volcanic tuffs (e.g. rhyolite tuff) and in a wide range of geological settings. Erionite-K has been used as a noble-metal-doping catalyst in a hydrocarbon cracking process and studied for its use in agricultural applications (i.e. in fertilizers and odor control in livestock production) (IARG, 1987a; NTP, 2004). The characteristics that define these bricks units are variable.

This may be due to the presence of: the materials used; manufacture processes; and dominate conditions. All of these mechanisms led to the creation of different deterioration forms, such as unequal settlements, collapsing because of the internal architectural features, and water saturation. In terms of the results obtained from the haciendas of mining, we can say that there were no great differences as to the composition of the materials, except for the presence of metals in the hacienda of benefit. We recommend that for greater theoretical and practical knowledge about adobe haciendas mining, it is necessary to analyze various samples from different mining districts and of different periods.

\section{Acknowledgements}

Our thanks to the laboratory LICAMM for its support in the realization of the analysis of X-ray diffraction and the SEM. Also, special thanks to M. C. Ofelia Perez Arvizu in the preparation and measurement of samples analyzed in the laboratory ultraclean ICP-MS from the National Autonomous University of Mexico (UNAM), Juriquilla-Queretaro. 
a

001
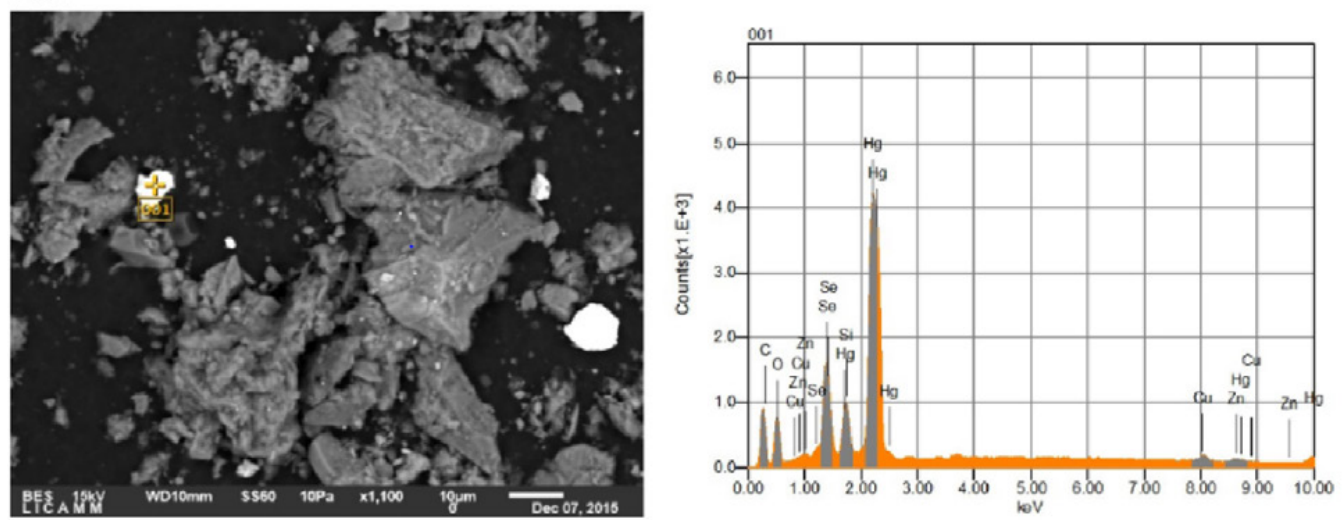

$\begin{array}{lllllllllll}\text { Volt } & : 15.00 \mathrm{kV} & \text { Acquisition } & \text { Condition } & \text { Formula } & \text { mass\% } & \text { Atom\% } & \text { Sigma } & \text { Net } & \text { K ratio } & \text { Line } \\ \text { Mag. } & : \times 1,100 & \text { Instrument } & : 6010 \mathrm{LA} & \mathrm{C} & 15.34 & 56.92 & 0.03 & 18510 & 0.0135696 & \mathrm{~K} \\ \text { Date } & : 2015 / 12 / 07 & \text { Volt } & : 15.00 \mathrm{kV} & \mathrm{O} & 5.67 & 15.80 & 0.04 & 14462 & 0.0347457 & \mathrm{~K} \\ \text { Pixel } & : 640 \times 480 & \text { Current } & :--- & \mathrm{Si} & 1.71 & 2.71 & 0.04 & 17696 & 0.0254004 & \mathrm{~K} \\ & & \text { Process Time } & : \mathrm{T} 1 & \mathrm{Cu} & 5.14 & 3.61 & 0.19 & 5780 & 0.0986123 & \mathrm{~K} \\ & & \text { Live Time } & : 30.00 \mathrm{sec} . & \mathrm{Zn} & 3.93 & 2.60 & 0.22 & 3772 & 0.0763301 & \mathrm{~K} \\ & & \text { Real Time } & : 30.55 \mathrm{sec} . & \mathrm{Se} & 9.12 & 5.15 & 0.11 & 50926 & 0.1404869 & \mathrm{~L} \\ & & \text { DeadTime } & : 2 \% & \mathrm{Hg} & 59.07 & 13.12 & 0.27 & 251618 & 0.8008225 & \mathrm{M}\end{array}$

$b$

\section{4}

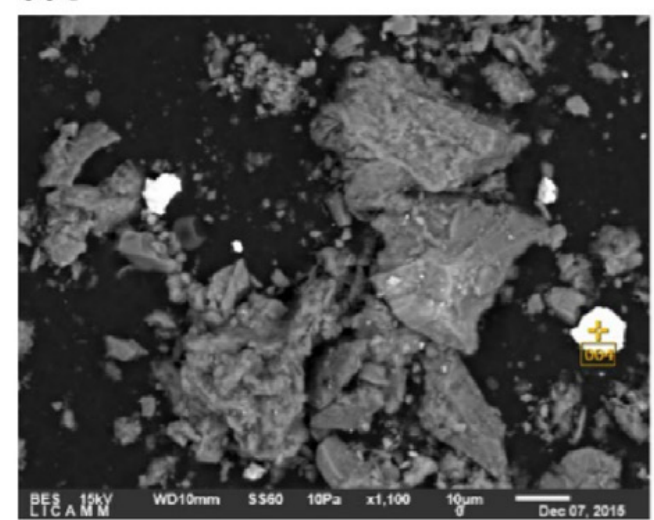

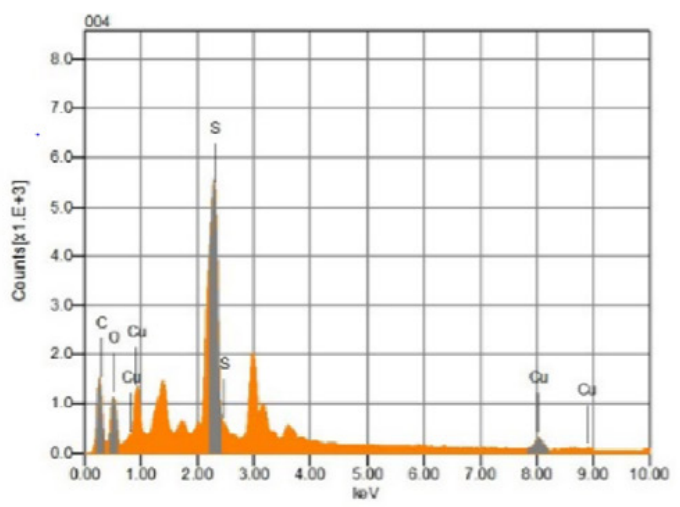

$\begin{array}{lllll}\text { Volt } & : 15.00 \mathrm{kV} & \text { Acquisition } & \text { Condition } & \text { Formula } \\ \text { Mag. } & : \times 1,100 & \text { Instrument } & : 6010 \mathrm{LA} & \mathrm{C} \\ \text { Date } & : 2015 / 12 / 07 & \text { Volt } & : 15.00 \mathrm{kV} & \mathrm{O} \\ \text { Pixel } & : 640 \times 480 & \text { Current } & :-- & \mathrm{S} \\ & & \text { Process Time } & : \text { T1 } & \mathrm{Cu} \\ & & \text { Live Time } & : 30.00 \mathrm{sec} . & \text { Total } \\ & & \text { Real Time } & : 30.78 \mathrm{sec} . & \\ & & \text { DeadTime } & : 2 \% & \\ & & \text { Count Rate } & : 13045.00 \mathrm{CPS} & \end{array}$

\section{mass $\%$ \\ 46.18}

12.91

17.54

23.37

100.00

Atom\%

69.07

14.49

9.83

6.61

100.00
Sigma Net

0.08

0.09

0.10

0.34
29468

21400

135349

17307

$\mathrm{K}$ ratio 0.0216030

0.0514161

0.2317031

0.2952731
Line

$\mathrm{K}$

K 


\section{References}

Achenza, M., Sanna, U., 2006, Il manuale tematico della terra cruda, Manuali di recupero dei centri storici della Sardegna: Cagliari, DEI, 126 p.

Alexander, R.T., 1997, Settlement Patterns of the Late Colonial Period in Yaxcaba Parish, Yucatán, México: Implications for the Distribution of Land and Population before the Caste War, in Gasco, J., Smith, G.C., Fournier-Garcia, P. (eds.), Approaches to the Historical Archaeology of México, Central, and South America: Institute of Archaeology, University of California, 38, $2940 \mathrm{p}$.

Alexander, R.T., 2004, Yaxcabá and the caste war of Yucatán: an archaeological perspective: Albuquerque, University of New Mexico Press, 207 p.

Antúnez, F., 1964, Monografía Histórica y Minera sobre el Distrito de Guanajuato: Distrito Federal, Consejo de Recursos Naturales no Renovables, 588 p.

Atzeni, G., Pia, G., Sanna, U., Spanu, N., 2008, A fractal model of the porous microstructure of earth-based materials: Constructive Building Materials, 22, 1607-1613.

Brannon, J., Joseph, G.M., 1991, Land, labor \& capital in modern Yucatán: essays in regional history and political economy: Tuscaloosa, University of Alabama Press, 344 p.

Benavides, A., 1985, Notas sobre la arqueología histórica de la Hacienda Tabi, Yucatán: Revista Mexicana de Estudios Antropológicos, 31, 45-58.

Camarillo-Ramírez, L.E., Cortez-Barroso, M.D., 2015, Catálogo del Archivo histórico 1927-1980: H. Congreso del Estado de Guanajuato, 833 p.

Chance, J.K., 2003, Haciendas, Ranchos, and Indian Towns: A Case Study from the Late Colonial Valley of Puebla: Ethnohistory, 50, $15-45$.
Chevalier, F., 1963, Land and society in colonial México; the great hacienda: Berkeley, University of California Press.

Fournier-Garcia, P., 1997, Tendencias de Consumo en México durante los Periodos Colonial e Independiente, in Gasco, J., Smith, G.C., Fournier-Garcia, P. (eds.), Approaches to the Historical Archaeology of México, Central, and South America: Institute of Archaeology, University of California, 38, 49-58.

Fournier-Garcia, P., Mondragon, L., 2003, Haciendas, Ranchos, and the Otomi Way of Life in the Mezquital Valley, Hidalgo, México. Ethnohistory 50, 47-68.

González Sánchez, I., 1997, Haciendas, Tumultos y Trabajadores Puebla-Tlaxcala: Serie Manuales. México, D.F., INAH, 1778-1798.

Heathcote, K.A., 1995, Durability of earthwall buildings: Construction Build Mater, 9, 185-189.

Houben, H., Guillaud, H., 1994, Earth Construction: A Comprehensive Guide, ITDG Publishing, London, UK, 376 p.

International Agency for Research Cancer (IARC), 1987a, Silica and some silicates. IARC Monographs on the Evaluation of the Carcinogenic Risk of Chemicals to Humans, 42, 1-239, PMID: 2824337.

Jarquín, M.T., 1990, Origen y evolución de la hacienda en México, siglos XVI al XX: memorias del simposio realizado del 27 al 30 de septiembre de 1989, $1^{\text {a }}$ ed. Zinacantepec, Edo. de México [México City]: Colegio Mexiquense; Universidad Iberoamericana: Instituto Nacional de Antropología e Historia.

Jiménez-Delgado, M.G., Canas-Guerrero, I., 2006, Earth building in Spain: Construction and Building Materials, 20, 9, 679-690.

Kemp, B., 1999, Soil (Including Mud-Brick Architecture), in Nicholson, P.T., Shaw, I. (ed.), Ancient Egyptian Materials and Technology: Cambridge University Press, Cambridge, 79-103. ISBN: 0521452570. 
Liberotti, G., Daneels, A., 2012, Adobes en arquitectura monumental: análisis químicofísicos, arqueología y reconstrucción 3D para determinar las técnicas constructivas en los sitios La Joya (México) y Arslantepe (Turquía): Boletín de la Sociedad Geológica Mexicana, 64(1), 79-89.

Meyers, A., D.L. Carlson, D.L., 2002, Peonage, Power Relations and the Built Environment at Hacienda Tabi, Yucatán, México. International Journal of Historical Archaeology, 6, 225-252.

Mori, L., Gomez-Tuena, A., Schaaf, P., Goldstein, S.L., Perez-Arvizu, O., SolisPichardo, G., 2009, Lithospheric removal as a trigger for flood basalt magmatism in the Trans-Mexican Volcanic Belt: Journal of Petrology, 50(1 1), 2157-2186.

Morner, M., 1973, The Spanish American Hacienda, A Survey of Recent Research and Debate: Hispanic American Historical Review, 53, 183-216.

National Toxicology Program, Department of Health and Human Services (NTP), 2004, Erionite: Report on Carcinogens, 14, III 14-III1 15, PMID: 21089873.

Norma Mexicana NMX-AA-21-1985, Protección al ambiente-contaminación del suelo - residuos sólidos municipales determinación de materia orgánica: Diario Oficial de la Federación de fecha 6 de Noviembre de 1992.

Norma UNE-EN1936, 2006, Métodos de ensayo para piedra natural, Determinación de la densidad real y aparente y de la porosidad abierta y total.
Norma UNE-EN1926, 2006, Métodos de ensayo para piedra natural, Determinación de la resistencia a la compresión.

Orozco, R.V., Orozco, Y.Y., 1992, La presas de jales en México, criterios básicos para su proyecto, construcción y operación: XVI Reunión Nacional de Mecánica de Suelos, Zacatecas, México.

Sengupta, M., 1993, Environmental impacts of mining monitoring, ristoration and control: Lewis Publishers, USA, 447 p.

Smith, E.W., Austin, G.S., 1989, Adobe, PressedEarth, and Rammed-Earth Industries in New Mexico: New Mexico Bureau of Mines \& Mineral Resources, a division of New Mexico Institute of Mining \& Technology, Bulletin, 127, 60 p.

Smith, E.W., Austin, G.S., 1996, Adobe, PressedEarth, and Rammed-Earth Industries in New Mexico: Revised edition. Socorro: New Mexico Bureau of Mines and Mineral Resources, Bulletin 159, 72 p.

Steen, C.R., 1977, Pajarito Plateau Archaeological Survey and Excavations: Los Alamos Scientific Laboratory, Los Alamos, New Mexico, LASL-77-4, 70 p.

Taylor, W.B., 1972, Landlord and peasant in colonial Oaxaca:. Stanford, California, Stanford University Press.

Van Young, E., 1983, Mexican Rural History Since Chevalier, The Historiography of the Colonial Hacienda: Latin American Research Review, 18, 5-61.

Wolf, E.R., Mintz, S., 1957, Haciendas and Plantations in Middle America and the Antilles: Social and Economic Studies 6, 380-411. 